\title{
Design of driven piles in sand
}

\author{
M. F. RANDOLPH,* J. DOLWIN $\dagger$ and R. BECK $\ddagger$
}

Estimation of the axial capacity of piles driven into sand involves considerable uncertainty, and design rules are generally not consistent with the physical processes involved. This Paper reviews current understanding of the factors that determine the axial capacity of piles driven into sand, and outlines a new framework for design which takes account of the physical processes, is consistent with the existing database of load test results, and is sufficiently flexible to permit refinement as new data become available. It allows for the effects of confining stress on the frictional and compressibility characteristics of sand, and hence on endbearing capacity. In keeping with field observations, shaft friction is assumed to degrade with driving of the pile past a particular location, from an initial maximum value linked to the local end-bearing capacity. The resulting design approach is compared with field data, and effects of factors such as the direction of loading are discussed.

KEYWORDS: bearing capacity; design; failure; piles; sands; silts.
L'estimation de la résistance axiale de pieux battus dans du sable présente une grande incertitude et les lois de conception ne sont généralement pas en accord avec les processus physiques impliqués. L'article passe en revue les connaissances usuelles permettant de déterminer la résistance axiale de pieux battus dans du sable et présente une nouvelle méthode de conception qui intègre les processus physiques, est en accord avec les bases de données d'essais de chargement disponibles et est suffisamment flexible pour permettre leur mise à jour lorsque de nouvelles données sont disponibles. Elle tient également compte de l'influence de la contrainte de confinement sur les caractéristiques de frottement et de compressibilité du sable et donc sur la résistance à la pointe. Lorsque le pieu dépasse au cours du battage une position particulière, le frottement latéral est supposé, pour rester en accord avec les observations in-situ, diminuer depuis une valeur maximale initiale fonction de la résistance à la pointe locale. Les résultats obtenus à l'aide de cette approche sont comparés aux données in-situ et l'influence de certains facteurs, tels que la direction de chargement ou la vitesse de déplacement du pieu, est étudiée.

\section{INTRODUCTION}

The axial capacity of piles driven into sand is arguably the area of greatest uncertainty in foundation design. Design guidelines such as those published by the American Petroleum Institute (API, 1984, 1991) are generally not consistent with the physical processes that dictate actual pile capacity. For example, the experimental observation of a gradual reduction in the rate of increase of pile capacity with embedment depth is allowed for by imposing limiting values of end-bearing and shaft friction beyond some critical depth. However, detailed profiles of shaft friction tend to show the opposite, with maximum values in the

Manuscript received 25 February 1993; revised manuscript accepted 7 December 1993.

Discussion on this Paper closes 1 December 1994; for

further details see $\mathrm{p}$. ii.

* University of Western Australia.

+ Wholohan Grill and Partners.

$\ddagger$ Amoco Production Company. vicinity of the pile tip and the lowest values near the ground surface.

Over the past decade, there has been intense debate over the appropriateness of current design methods for driven piles in sand. General concerns have been expressed over the detail of recommended design parameters, and also in respect of the conceptual models implied by the design methods. In particular, there has been widespread discussion of the use of limiting values of shaft friction and end-bearing, the treatment of partial displacement piles, and potential differences in tensile and compressive shaft capacity.

There is a need for new, high-quality field data on pile drivability and axial capacity in sand, particularly from piles of field scale, in order to help resolve some of these uncertainties. However, there is also a need for elucidation of the basic mechanisms that affect pile capacity, and for parametric studies using numerical and laboratory-scale physical models. 
This Paper reviews the physical processes at work during pile installation, and proposes a framework for a new design approach. At this stage, quantification of some aspects of the new design approach is preliminary, and significant research effort over the next few years will be needed to refine the approach. The principal aim has been to provide a methodology that has a sound physical basis and the potential to take due account of features such as absolute stress level, penetration ratio, degree of plugging, and tensile or compressive loading.

The present work does not consider the effects of cyclic loading on pile capacity. However, the form of the methodology is such that it would be straightforward to introduce additional parameters to address changes in radial effective stress acting on the pile shaft under the action of cyclic loading, particularly the reduction in local effective stresses due to densification of the soil around the pile. Similarly, while the design approach has been developed for silica sands, the methodology has the scope to deal with soils of other mineralogy and also provides a consistent approach for soils of differing compressibility. This offers the designer the ability to account gradually for the silt content within each sand stratum, avoiding the quantum jump between alternative design choices of silt or sand. Furthermore, the approach may be extended at a later date to provide a unified design framework applicable to both silica material and much more compressible calcareous soils.

Current design methods and the experimental basis for alternative approaches are reviewed in this Paper. Particular attention is paid to the debate over the existence of limiting values of end-bearing and shaft friction, and how values of key parameters are assumed to be affected by the type and relative density of the soil. Conceptual models of the physical processes involved during pile installation are drawn together, and the new design framework, based on those processes, is described. Preliminary quantitative assessment of the new approach is then presented, using the limited database of reasonable-quality pile load tests that are currently available. The principal areas of uncertainty are highlighted and research goals are suggested that will lead to improvement in the proposed design model.

\section{REVIEW OF CURRENT DESIGN METHODS}

Methods for estimating the capacity of driven piles in sand can be divided into two broad categories, based on fundamental parameters (friction angle, density and stiffness) or on the results of in situ tests. In the latter approach, the most common tests are the cone penetration resistance $q_{\mathrm{c}}$ and the standard penetration test (SPT) blowcount $N$. In this Paper design rules based on in situ tests are expressed in terms of an appropriately average cone resistance, on the understanding that design rules of a similar nature are available in the literature for other forms of in situ test. Perhaps the most widely used design method based on intrinsic soil properties is that contained in the API guidelines for the construction of fixed offshore platforms. The current guidelines were introduced in the 15 th edition (API, 1984) and have remained largely unchanged in the most recent edition (API, 1991). That method is used as a background for the discussion of alternative approaches.

The ultimate end-bearing resistance of a pile is generally expressed as

$$
q_{\mathrm{b}}=N_{\mathrm{q}} \sigma_{\mathrm{v}}{ }^{\prime} \text { or } q_{\mathrm{b}}=k_{\mathrm{c}} q_{\mathrm{c}}
$$

where $N_{q}$ is a bearing capacity factor, $\sigma_{\mathrm{v}}{ }^{\prime}$ is the in situ effective overburden stress and $k_{\mathrm{c}}$ is the factor relating pile end-bearing to the cone resistance $q_{\mathrm{c}}$. Typical values of $N_{\mathrm{q}}$ range from 8-12 for loose sand to over 40 for very dense sand (e.g. API, 1991). Similar values for $k_{\mathrm{c}}$ lie in the range 0.4 0.6 (Bustamante \& Gianeselli, 1982; Kraft, 1990). In the API guidelines, limiting values are put on the absolute value of end-bearing resistance, corresponding to an overburden stress of about $240 \mathrm{kPa}$ (a depth of $20-25 \mathrm{~m}$ in saturated soil). is

For shaft friction, the corresponding approach

$\tau_{\mathrm{s}}=K \tan \delta \sigma_{\mathrm{v}}^{\prime} \quad$ or $\quad \tau_{\mathrm{s}}=q_{\mathrm{c}} / \alpha$

where $K$ is an earth pressure coefficient relating the normal effective stress acting around the pile at failure to the in situ effective overburden stress, $\tan \delta$ is the coefficient of friction between pile and soil and $\alpha$ is a coefficient that varies in the range 60-120 (Bustamante \& Gianeselli, 1982). In the API guidelines, the value of $K$ is taken as 0.8 for a partial displacement pile and 1 for a full displacement pile, irrespective of the direction of loading (tensile or compressive). In both approaches, limiting values of shaft friction ranging from $40 \mathrm{kPa}$ (loose) to $120 \mathrm{kPa}$ (very dense) are specified. In the API guidelines, the limiting value of shaft friction for each category of soil is reached at an effective overburden stress of about $220 \mathrm{kPa}$. In design, it is common to adopt uniform values of the empirically evaluated parameters $K$ and $\alpha$ over the full depth of sand penetrated by the pile. However, in reality these parameters will vary along the pile shaft, and the proposed design approach will consider local values of such parameters.

The assumption in the API guidelines of limiting values of end-bearing and shaft friction being 
reached at an absolute stress level (or depth), independently of pile diameter, contrasts with recommendations by Vésic $(1967,1970)$ where the critical depth is expressed in terms of the pile diameter $d$ and varies from $10 d$ for loose/medium sand up to $20 d$ for dense sand (see Poulos \& Davis, 1980). Such contradictions are a direct result of the limited database of pile load tests, where lack of detail in the soil data, and natural variability, prevent conclusive interpretations. In addition, most of the piles considered fall in a rather narrow range of diameter and penetration, which precludes definitive assessment of the relative importance of effective stress level, absolute pile length or normalized length $L / d$.

It should be emphasized that in the API approach, for a given soil type, the distribution of shaft friction is assumed to be identical, regardless of the diameter or penetration of the pile. Thus, at depths less than the critical depth at which the limiting value of shaft friction is reached, the pile shaft capacity would increase with the square of the embedment. Below the critical depth, there would be a linear increase in shaft capacity.

\section{End-bearing resistance}

The assumption that end-bearing resistance increases linearly with depth up to some limiting value is an idealization that has little support nowadays and is difficult to explain in physical terms. A more widely held view is that, for a homogeneous sand deposit, the end-bearing resistance continues to increase with increasing depth, but at a gradually decreasing rate. The gradual reduction in the rate of increase of endbearing resistance with increasing stress level can be attributed to two effects.

(a) As the mean stress in the failure region increases (with depth), the friction angle of the soil will decrease (Bolton, 1986). Thus the bearing capacity factor $N_{\mathrm{q}}$ in equation (1) should be reduced as the overburden stress increases. This effect has been quantified by Randolph (1985) and Fleming, Weltman, Randolph \& Elson (1992), and the resulting design charts are presented in Fig. 1, where $\phi_{\mathrm{cv}}$ is the (effective) critical state friction angle and $I_{\mathrm{d}}$ is the relative density, of the soil.

(b) The failure beneath the pile tip is a confined failure (with no rupture extending to a free surface), which entails the end-bearing resistance being affected by the stiffness of the soil in addition to its strength. Essentially, the bearing capacity factor $N_{\mathrm{q}}$ is an increasing function of the rigidity index $I_{\mathrm{r}}$ (ratio of stiffness to strength). Since the stiffness of noncohesive soil increases with the mean stress level to some power less than unity (typically about 0.5 ), the rigidity index will reduce with depth, resulting in a decrease of $N_{\mathrm{q}}$ with depth. Kulhawy (1984) has addressed this aspect of end-bearing resistance.

In order to combine the effects of mean stress level on friction angle and rigidity index, it is necessary to develop a semi-analytical model of deep bearing failure. The most promising approach appears to be through an analogy with spherical cavity expansion that has been used widely (e.g. Vésic, 1975). The use of cavity expansion limit pressures to estimate end-bearing resistance is developed in more detail below.

\section{Shaft friction}

While the interface friction angle $\delta$ between pile and soil can be measured with reasonable accuracy (Kishida \& Uesugi, 1987; Jardine, Everton \& Lehane, 1992), there is considerable uncertainty and debate over the appropriate choice of

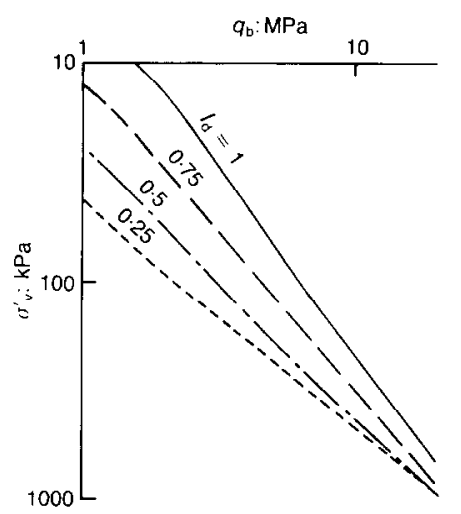

(a)

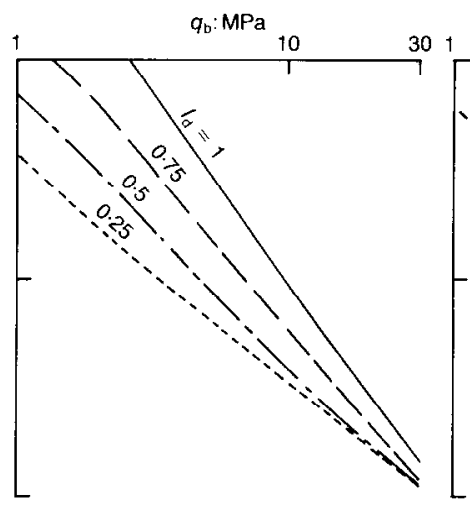

(b)

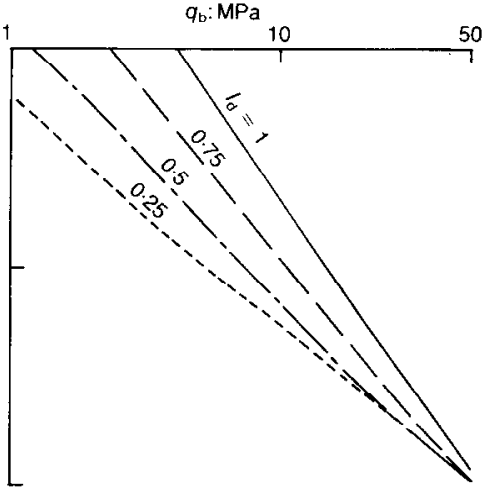

(c)

Fig. 1. Design chart for end-bearing capacity (after Fleming et al., 1992): (a) $\phi_{\mathrm{cv}}=27^{\circ}$; (b) $\phi_{\mathrm{cv}}=30^{\circ}$; (c) $\phi_{\mathrm{cv}}=33^{\circ}$ 


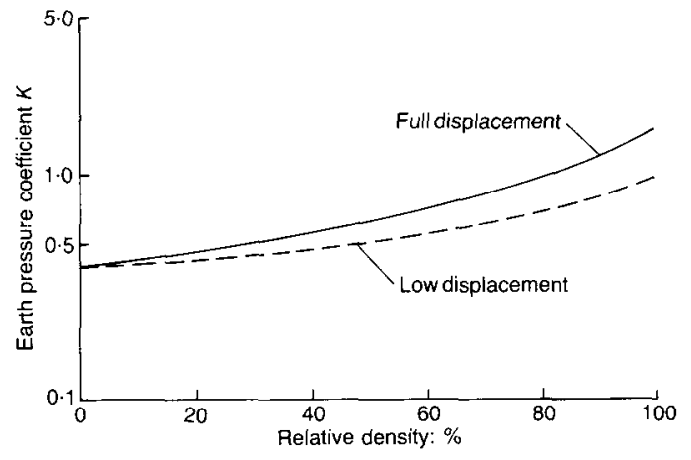

Fig. 2. Variation of stress ratio $K$ with relative density (after Kraft, 1990)

the horizontal stress coefficient $K$ and the extent to which limiting values of shaft friction should be imposed. Kraft (1990) has presented an alternative approach for estimating $K$, based purely on relative density of the soil (but independent of grain size) and effective area ratio of the pile (full or partial displacement). The suggested variation of $K$, shown in Fig. 2, is based on field test data, assuming interface friction angles of $\delta=0.7 \phi_{\max }$ for silica sands and $\delta=0.6 \phi_{\max }$ for calcareous sands, where $\phi_{\max }$ is the peak (effective) friction angle for the soil. (These values of $\delta$ adopted by Kraft are not necessarily consistent with laboratory data such as those presented by Kishida \& Uesugi (1987) and Jardine et al. (1992), and will in any case vary with the relative roughness of the pile shaft.)

For most soils, Kraft's approach leads to lower values of shaft friction than the API guidelines. However, he recommends that no limiting value of shaft friction should be imposed, with the result that his approach generates lower shaft capacities for short piles but higher shaft capacities for long piles. This contrasts with the conclusions of Hossain \& Briaud (1991) that the API method tends to be conservative for short piles, but overestimates the capacity of long piles, with the crossover being at about 40 pile diameters. Overall, the profiles of shaft friction derived from Kraft's approach are not in keeping with experimental evidence that shows average shaft friction values that appear to approach a limit at large depths.

Kulhawy (1984) has argued that the experimental observation of limiting shaft friction arises from a combination of decreasing friction angle with depth (or stress level) and decreasing $K$ values with depth, due to the natural tendency for the in situ stress ratio $K_{0}$ to decrease with depth.

The effect of a decreasing friction angle with an increasing stress level has been accounted for in the approach proposed by Fleming et al. (1992).

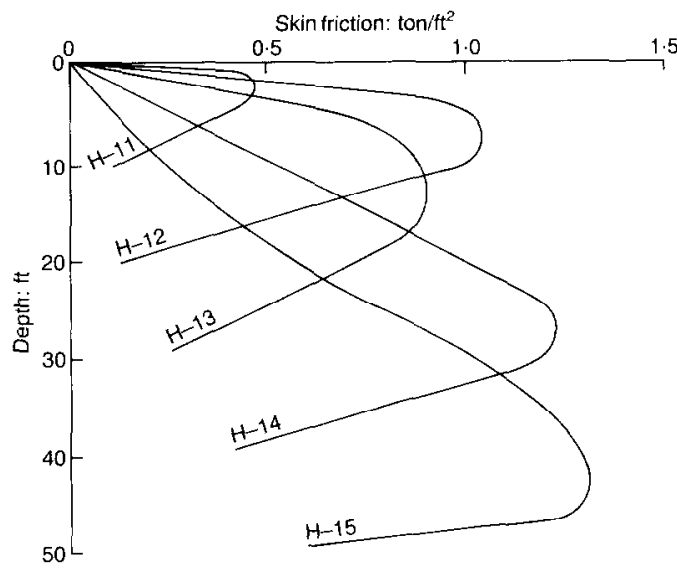

Fig. 3. Distribution of shaft friction along pile shafts (after Vésic, 1970)

They suggest taking $K$ as a constant proportion of $N_{\mathrm{q}}\left(K=0.02 N_{\mathrm{q}}\right)$, together with an interface friction angle of $\phi_{\mathrm{cr}}$, which leads to ratios of shaft friction to end-bearing of

$$
\tau_{\mathrm{s}}=0.02 q_{\mathrm{b}} \tan \phi_{\mathrm{cv}}
$$

While this approach leads to ratios in keeping with field measurements (e.g. Vésic, 1970), the shaft capacities of long piles are generally overestimated.

An important effect that has been ignored in all the approaches considered so far is the wellestablished observation that the local shaft friction at any level varies with pile penetration. This has been reported by Vésic (1970) (see Fig. 3), Hanna \& Tan (1973), Lehane, Jardine, Bond \& Frank (1993) and many other researchers. Heerema (1980) has emphasized the importance of the effect, which he refers to as friction fatigue, in pile drivability studies.

A recent design approach that allows for degradation of friction due to the length of pile installed is that of Toolan, Lings \& Mirza (1990), who describe two approaches, both of which allow for friction degradation, but in different ways. The two methods are outlined as follows.

(a) Based on the experimental observation that the average shaft friction reaches a limiting value at quite shallow penetrations, an empirical correlation of average measured shaft friction with relative density is proposed, as detailed in Table 1 . The actual distribution of shaft friction is assumed to be triangular, with the value at the pile tip being twice the average value. For soils of intermediate relative densities to those shown, a linear interpolation is used. The assumption of a triangular distribution of shaft friction 
Table 1. Design approach for average shaft friction (Toolan et al., 1990)

\begin{tabular}{l|c|c|c|c|c}
\hline Soil description & \multirow{2}{*}{$\begin{array}{l}\text { Relative } \\
\text { density }\end{array}$} & \multicolumn{4}{|c}{ Shaft friction: kPa } \\
\cline { 3 - 6 } & & \multicolumn{2}{|c|}{ Open-ended piles } & \multicolumn{2}{c}{ Closed-ended piles } \\
\cline { 3 - 6 } & & Average & Tip & Average & Tip \\
\cline { 3 - 6 } & & 12 & 24 & 15 & 30 \\
Loose & 25 & 20 & 40 & 25 & 50 \\
Medium dense & 50 & 40 & 80 & 50 & 100 \\
Dense & 75 & 80 & 160 & 100 & 200 \\
Very dense & 90 & & & &
\end{tabular}

broadly fits the data of Vésic (1970) shown in Fig. 3, and leads to gradual reduction of shaft friction at any given level as the pile penetration is increased. Thus, effects of friction degradation are accounted for, at least in a simplistic way.

(b) The alternative approach of Toolan et al. (1990) adopts a fixed ratio of $\beta=\tau_{\mathrm{s}} / \sigma_{\mathrm{v}}{ }^{\prime}$, which is a function of relative density and pile penetration and applies over the bottom $10 \mathrm{~m}$ of the pile. The proposed correlation is shown in Fig. 4 for full displacement piles, with values for unplugged open-ended piles bcing $20 \%$ lower. For piles that are embedded beyond $10 \mathrm{~m}$, the shaft friction down to $10 \mathrm{~m}$ above the pile tip is calculated using a value of $\beta$ that is the lower of 0.24 and the value from Fig. 4 . The value of $\beta=0.24$ reflects degraded friction due to two-way plastic slip during installation.
The approach proposed by Toolan et al. (1990) essentially provides an upper and lower bound to the ratio $\beta=\tau_{\mathrm{s}} / \sigma_{\mathrm{v}}{ }^{\prime}$, with a sharp jump from the upper value (in the lower $10 \mathrm{~m}$ of the pile) to the lower value over the remainder of the pile shaft. The sudden reduction in $\beta$ is clearly an idealization, and the fixed lower limit of $\beta=0.24$ does not model the gradual effect of friction degradation observed in the field. However, it represents a reasonable attempt at a design approach that differentiates between high friction near the pile tip and reduced, degraded, shaft friction over much of the length of the pile.

\section{PROPOSFD FRAMEWORK FOR NFW DESIGN METHODS}

A new framework for calculating pile capacity in sand is now presented. At this stage, some of the quantitative details of the proposed design

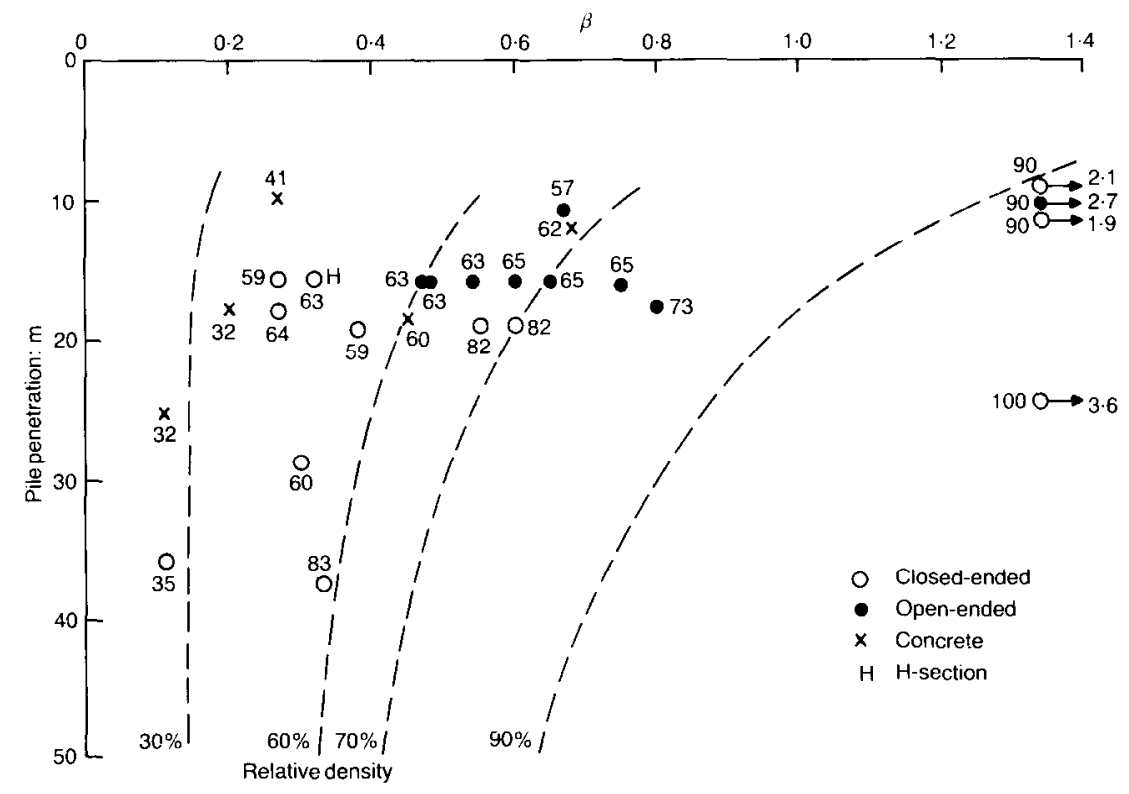

Fig. 4. Proposed $\beta$ values over bottom $10 \mathrm{~m}$ of pile (after Toolan et al., 1990) 
method require further research. Preliminary suggestions are given for key parameters.

\section{End-bearing capacity}

Although it is convenient to express the endbearing capacity of a pile in terms of a bearing capacity factor multiplied by the in situ vertical effective stress, as in equation (1), the bearing capacity factor will be a function of both the strength (or frictional angle) and the rigidity index $\left(G / p^{\prime}\right.$, where $G$ is the shear modulus and $p^{\prime}$ the mean effective stress) of the material. These quantities vary differently with the absolute effective stress level. In addition, the relative magnitude of the in situ horizontal and vertical stresses will affect the bearing capacity factor (Houlsby \& Hitchman, 1988).

In principle, these effects can be quantified through detailed numerical analysis using an appropriate soil model. However, there is no generally accepted model for the stress-strain response of granular material over the enormous strain levels relevant to bearing failure, and the computational effort to conduct a full parametric study would be daunting. An alternative is to use the analogy between spherical cavity expansion and bearing failure (Gibson, 1950), as depicted in Fig. 5. A rigid cone of soil is assumed beneath the pile tip, with the angle $\alpha$ determined by the friction angle of the soil. Outside the conical region there is a zone of soil, nominally under isotropic stress equal to the limit pressure for spherical cavity expansion. It can be shown that the

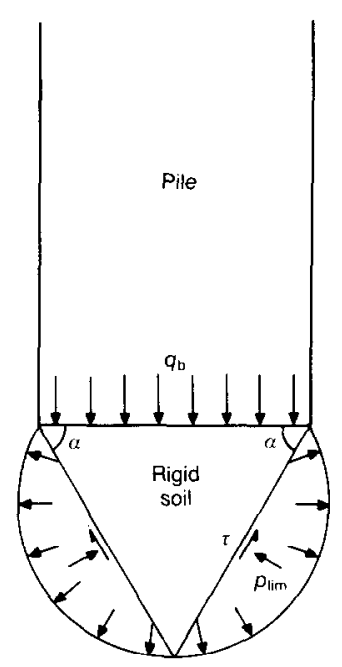

Fig. 5. Relation of cavity expansion limit pressure and end-bearing capacity relationship between end-bearing pressure $q_{\mathrm{b}}$ and the limit pressure $p_{\text {lim }}$ is

$$
q_{\mathrm{b}}=p_{\text {lim }}\left(1+\tan \phi^{\prime} \tan \alpha\right)
$$

Assuming that the soil immediately beneath the pile tip has been sheared to its ultimate state, the friction angle $\phi^{\prime}$ should be taken as $\phi_{c v}$ and the angle $\alpha$ may be taken as $\left(45+\phi_{\mathrm{cv}} / 2\right)$.

Equation (4) can also be used for the cone resistance $q_{\mathrm{c}}$ by taking $\alpha$ as $60^{\circ}$ (the cone angle) and $\phi^{\prime}$ as $\delta$, the interface friction angle between cone and soil. Of course, in many instances cone penetration data may be available directly, and the profile of cone resistance can be used as the basis for estimating pile capacity, using appropriate averaging routines (e.g. de Ruiter \& Beringen, 1979). However, the cavity expansion approach, as outlined here, is useful for situations where no cone data are available and also in the understanding and interpretation of the cone data in terms of soil density and frictional characteristics.

The limit pressure for spherical cavity expansion can be evaluated through the closed-form expressions of Carter, Booker \& Yeung (1986) or Yu \& Houlsby (1991) (both solutions yield similar values). These solutions are based on an elasticperfectly plastic soil with a Mohr-Coulomb failure criterion and a constant rate of dilation, and require as input

(a) the in situ mean effective stress $p_{0}^{\prime}$

(b) the friction angle for the soil $\phi^{\prime}$

(c) the dilation angle for the soil $\psi$

(d) the shear modulus $G$ (an equivalent value, allowing for the non-linear stress-strain response of sand)

(e) Poisson's ratio $v$ (which has a relatively small effect).

The friction and dilation angles are assumed constant in the plastic region around the cavity. However, the numerical solutions for cavity expansion published by Collins, Pender \& Wang Yan (1992), where the friction and dilation angles varied as the soil approached critical state conditions, show that the appropriate friction and dilation angles to use in these solutions are average values between the initial statc $\left(\phi^{\prime}=\phi_{\max }, \psi-\right.$ $\left.\psi_{\max }\right)$ and ultimate state $\left(\phi^{\prime}=\phi_{\mathrm{cv}}, \psi=0\right)$. Thus $\bar{\phi}^{\prime}=0.5\left(\phi_{\max }+\phi_{\mathrm{cv}}\right)$ and $\psi=0.5 \psi_{\max }$.

Following the work of Bolton $(1986,1987)$, the peak friction and dilation angles can be linked directly to the relative density $I_{\mathrm{d}}$ and the mean effective stress. These correlations (and the averaging process above) lead to effective friction and dilation angles for the cavity expansion solution of

$$
\begin{aligned}
& \bar{\phi}^{\prime}=\phi_{\mathrm{cv}}+1 \cdot 5 I_{\mathrm{r}} \\
& \bar{\psi}=1.875 I_{\mathrm{r}}
\end{aligned}
$$


where

$$
\begin{aligned}
& I_{\mathrm{r}}=5 I_{\mathrm{d}}-1 \quad \text { for } \quad p^{\prime} \leqslant 150 \mathrm{kPa} \\
& I_{\mathrm{r}}=I_{\mathrm{d}}\left[5 \cdot 4-\ln \left(p^{\prime} / p_{\mathrm{a}}\right)\right]-1 \\
& \text { for } p^{\prime}>150 \mathrm{kPa}
\end{aligned}
$$

and $p_{\mathrm{a}}$ is atmospheric pressure $(100 \mathrm{kPa})$.

The shear modulus can be correlated with the mean effective stress level and either the void ratio $e$ or the relative density $I_{\mathrm{d}}$. Most of these correlations have originated from small-strain testing, which has led to expressions for the initial tangent shear modulus $G_{0}$ of (Richart, Hall \& Woods, 1970)

$$
\frac{G_{0}}{p_{\mathrm{a}}} \approx S \frac{\left(e_{\mathrm{c}}-e\right)^{2}}{(1+e)}\left(\frac{p^{\prime}}{p_{\mathrm{a}}}\right)^{n}
$$

where $S$ varies from 300 to $700, e_{\mathrm{c}}$ varies from $2 \cdot 2$ to 2.9 and $n$ varies from 0.4 to 0.5 . Lo Presti (1987) has suggested a correlation with relative density of the form

$$
\frac{G_{0}}{p_{\mathrm{a}}} \approx S \exp \left(c_{1} I_{\mathrm{d}}\right)\left(\frac{p^{\prime}}{p_{\mathrm{a}}}\right)^{n}
$$

where $S$ is about $600, c_{1}$ is 0.7 and $n$ is about 0.43 .

Since a number of correlations are available for relative density, it is suggested that equation (9) may prove more useful, with the coefficient $S$ being varied to reflect the silt content (essentially allowing for different maximum and minimum void ratios in the correlation of equation (8)). In the first instance, it is suggested that constant values of $S=400, c_{1}=0.7$ and $n=0.5$ be adopted for a clean silica sand, with the value of $S$ being reduced for more compressible materials (silts or calcareous sands). A preliminary correlation of $S$ with silt content is suggested in Table 2 .

It must be emphasized that the cavity expansion solution is based on an idealized soil model, and the correlations already given for the shear modulus are limited by real behaviour which shows that values of the elastic parameters and the correlation index $n$ are all affected by strain level. However, in spite of these limitations the approach appears to yield realistic estimates of bearing capacity, and to capture the significant effect of stress level on the traditional bearing capacity factor $N_{\mathrm{q}}$.

Table 2. Suggested variation of $S$ (equation (9)) with silt content

\begin{tabular}{c|c|c|c|c}
\hline $\begin{array}{c}\% \text { passing } \\
0.2 \mathrm{~mm} \text { sieve }\end{array}$ & $0-5$ & $5-10$ & $10-15$ & $15-30$ \\
\hline Value of $S$ & 400 & 200 & 100 & 75 \\
\hline
\end{tabular}

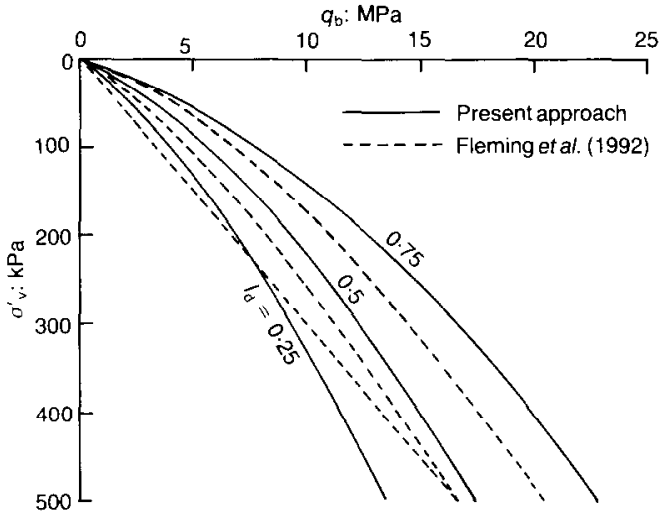

Fig. 6. Comparison of end-bearing capacity profiles

Predictions of limiting end-bearing pressure obtained from the cavity expansion approach are compared with the design charts of Fleming et al. (1992) in Fig. 6, for three different values of relative density, taking $\phi_{\mathrm{cv}}=30^{\circ}$ (and $S=400$ ). Overall, there is excellent agreement between the two sets of curves but, as expected, the cavity expansion approach leads to greater curvature of the end-bearing profiles. This is due to the effect of decreasing rigidity index with increasing depth.

The agreement between the new cavity expansion approach, allowing for the ratio $q_{\mathrm{b}} / p_{\text {lim }}$ given by equation (4) and the design approach of Fleming et al., is encouraging, particularly in view of good correlations of the latter method with pile test data (e.g. Neely, 1990). However, the cavity expansion approach has much greater flexibility for future use, since it can allow for the compressibility of different soils. It is also straightforward to program into a spreadsheet for design purposes. Fig. 7 shows the effect of varying the shear

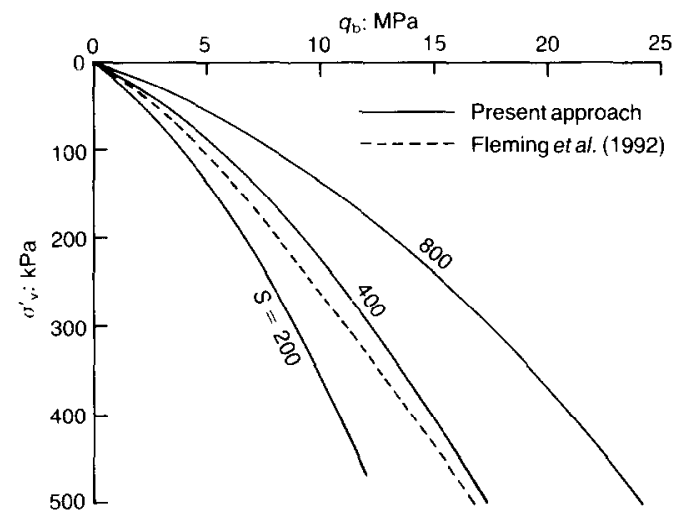

Fig. 7. Effect of varying shear modulus on end-bearing capacity 
modulus by a factor of 0.5 or 2 , taking $S=200$ and 800 rather than the suggested value of 400 . It is clear that the stiffness of the soil has a significant effect on the calculated end-bearing capacity.

No limiting value of end-bearing should be stipulated: the tendency towards a limiting value is captured sufficiently by the cavity expansion approach. Field load tests have shown that extremely high values of end-bearing may be achieved for driven piles at relatively low displacements (e.g. Helfrich, Wiltsie, Cox \& Al Shafie, 1985).

\section{Peak shaft friction}

Experimental observations show that, even in a homogeneous sand deposit, the shaft friction does not increase linearly with depth. The shaft friction depends on the radial effective stress $\sigma_{\mathrm{r}}{ }^{\prime}$, which can be expressed as a ratio $K$ times the in situ vertical effective stress, and the interface friction angle $\delta$ between pile and soil. The latter quantity can be measured directly by interface shear tests, and is generally found to be a little lower than $\phi_{\mathrm{cv}}$. Although the key unknown quantity is the coefficient $K=\sigma_{\mathrm{r}}{ }^{\prime} / \sigma_{\mathrm{v}}{ }^{\prime}$, it is convenicnt to describc the shaft friction directly in terms of $\beta=\tau_{\mathrm{s}} / \sigma_{\mathrm{v}}{ }^{\prime}$. However, it must be emphasized that $\beta=K \tan \delta$, and the two separate components $K$ and $\tan \delta$ should be considered when estimating $\beta$.

The API guidelines, which suggest a constant (high) value of $\beta$ in the upper part of the pile and then a gradually decreasing value of $\beta$ (constant limiting shaft friction) over the lower part of the pile, are compared with the contrasting recommendations of Toolan et al. (1990) and typical field data in Fig. 8. It is clear that many different distributions of shaft friction could be chosen that would match the average shaft friction measured from a pile test. However, the instrumented pile tests of Vésic (1970) and Lehane et al. (1993) show that the highest values of $\beta$ occur near the pilc tip.

Following the approach of Heerema (1980) in relation to modelling friction fatigue in drivability analyses, it is suggested that a simplified profile of $\beta$ should be adopted, as shown in Fig. 8, with a peak value just behind the pile tip and decreasing monotonically for shallower depths. As more detailed field data are obtained, the precise position of the maximum $\beta$ value can be refined.

The distribution of shaft friction along the length of the pile is discussed more fully later. First it is necessary to consider the maximum value of $\beta$ to be assumed, just behind the pile tip.

The stress state in the soil just behind the advancing pile tip is intimately related to the endbearing pressure generated by the tip. As such, a logical approach is to assume that, at shaft failure, the radial effective stress is a fixed propor-

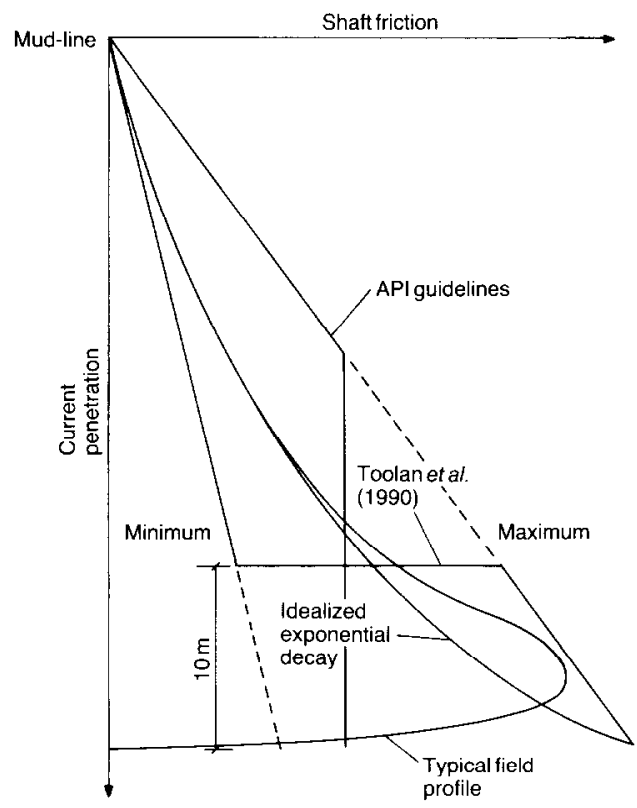

Fig. 8. Idealized and field profiles of shaft friction with depth

tion of the end-bearing pressure $q_{\mathrm{b}}$. This is equivalent to a relationship of the peak shaft friction $\tau_{\max }$ and end-bearing capacity $q_{\mathrm{b}}$ (or $\beta_{\max }$ and $N_{\mathrm{q}}$ )

$$
\frac{\tau_{\max }}{q_{\mathrm{b}}}=\frac{\beta_{\max }}{N_{\mathrm{q}}}=S_{\mathrm{t}} \tan \delta
$$

where $S_{\mathrm{t}}$ is the ratio of the radial effective stress acting in the vicinity of the pile tip at shaft failure to the end-bearing capacity.

Fleming et al. (1992) have suggested a value for the factor $S_{1}$ of 0.02 . Limited field data from instrumented tests support a value in that region, as shown in Fig. 9, although both sets of data shown require some qualification. The data from Vésic (1970) in Fig. 9 have been deduced from measured profiles of shaft friction down steel pipe piles of $457 \mathrm{~mm}$ diameter, installed at depths of between $3 \mathrm{~m}$ and $15 \mathrm{~m}$, assuming an interface friction angle of $\delta=\phi_{\max }-5^{\circ}$ (e.g. Beringen, Windle \& Van Hooydonk, 1979), giving $\delta=25^{\circ}$ for test $\mathrm{H}-11$ and $30^{\circ}$ for the other tests. The relationship of the angles $\delta$ and $\phi_{\max }$, although widely used in design, may tend to overestimate $\delta$, leading to an underestimate of the radial effective stress. The data from Lehane et al. (1993) are direct measurements of radial effective stress, with no load on the pile, from an instrumented pile of $100 \mathrm{~mm}$ diameter installed to depths of up to $6 \mathrm{~m}$. Lehane et al. point out that there is a tendency for the radial effective stress to increase as the pile is loaded, which would again lead to higher values 


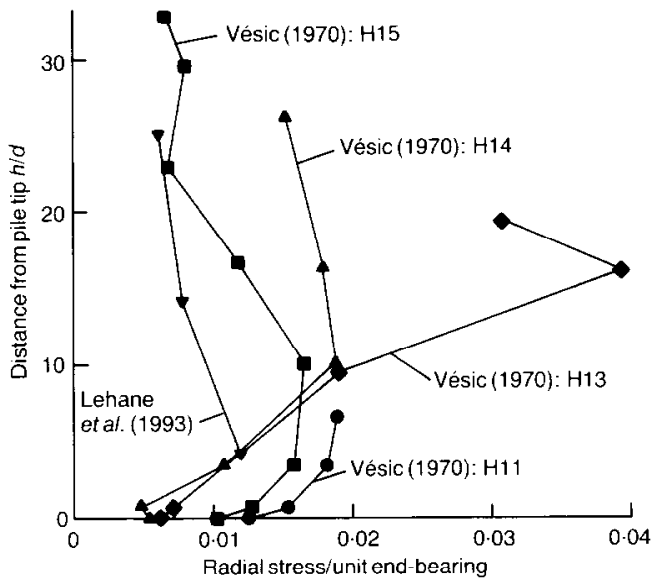

Fig. 9. Measured radial stress profiles near pile tip

of radial effective stress at the point of shaft failure. Both piles were closed-ended, and the general consistency of the data indicates that the factor $S_{t}$ in equation (10) is relatively independent of pile diameter and depth of embedment.

Vésic (1970) proposed a rclationship between $\tau_{\mathrm{s}} / q_{\mathrm{b}}$ and $\phi_{\max }$ of the form

$$
\tau_{\mathrm{s}} / q_{\mathrm{b}} \approx 0.1 \exp \left(-3 \tan \phi_{\max }\right)
$$

For friction angles in the range $35^{\circ}-45^{\circ}$, and taking $\delta=\phi_{\max }-5^{\circ}$, this relation implies values of $S_{1}$ in the range $0.005-0.02$. However, the relation is based on average values measured over the full pile. Peak values near the pile tip will be considerably higher.

Further guidance on expected values for $S_{\mathrm{t}}$ can be obtained from correlations for friction ratios for cone penetration tests, which tend to decrease with increasing friction angle, with values typically in the range $1-2 \%$ for sands (Douglas \& Olsen, 1981). At this stage, it is recommended that the peak friction behind the pile tip be estimated directly from friction sleeve measurements with the cone. In the absence of such data, a correlation based on that proposed by V'́sic (1970) (equation (11)) can be used to give an estimate of the radial effective stress, from which the shaft friction can then be calculated. A suggested expression for the factor $S_{\mathrm{t}}$ is

$$
S_{\mathrm{t}}=a \exp \left(-b \tan \phi_{\mathrm{cv}}\right)
$$

The argument for using $\phi_{\mathrm{cv}}$ rather than $\phi_{\max }$ in the exponential term is twofold. First, the constant volume friction angle is more readily measurable from disturbed samples and second, the soil in the immediate vicinity of the pile will have been sheared to its ultimate condition, in which case $\phi_{\mathrm{cv}}$ becomes more relevant than the peak friction anglc. As is shown later, reasonable agreement with field data is obtained with parameters $a=2$ and $b=7$, leading to $S_{\mathrm{t}}$ values in the range $0.02-0.05$ for $\phi_{c v}=27^{\circ}-33^{\circ}$. The corresponding friction ratios for typical values of $\delta$ will lie in the range $0.01-0.02$. This is clearly an area where further research is necessary in order to refine estimates of the ratio $S_{t}$.

\section{Shaft friction distribution along the pile shaft}

There is substantial field evidence that the shaft friction at any given level reduces as the pile is driven further into the ground. As indicated in Fig. 8, data from pile load tests indicate a maximum shaft friction at some distance behind the pile tip, with reducing (normalized) shaft friction at shallower depths. However, in the first instance a simpler distibution is proposed, similar to the exponential decay proposed by Heerema (1980).

Following Toolan et al. (1990), it is helpful to postulate a minimum value of $\beta$, which will be a function of the minimum ratio of $\sigma_{\mathrm{r}}{ }^{\prime} / \sigma_{\mathrm{v}}{ }^{\prime}$ (perhaps linked to the active earth pressure coefficient $K_{\mathrm{a}}$ ) and $\tan \delta$. This minimum value will be reached only with very long piles. At any given location, the shaft friction will degrade from the peak value (as already discussed) towards the minimum value, as an exponential function of the length of pile driven past that location. Thus the shaft friction at depth $z$ can be written in terms of the local value as

$$
\begin{aligned}
\beta(z) & =\tau_{\mathrm{s}} / \sigma_{v}{ }^{\prime} \\
& =\beta_{\min }+\left(\beta_{\max }-\beta_{\min }\right) \exp [-\mu(L-z) / d]
\end{aligned}
$$

where $\beta_{\max }=S_{\mathrm{t}} N_{\mathrm{q}} \tan \delta, L$ is the total embedded length of the pile, $d$ is the pile diameter and $z$ is the depth below ground level. Thus $(L-z) / d$ is the normalized length of pile driven past that particular location. The rate of the exponential decay is controlled by the parameter $\mu$, which may typically be of the order of $0 \cdot 05$. Fig. 10 shows example profiles of $\beta(z)$, based on $\beta_{\max }$ and $\beta_{\min }$ values of 1.0 and 0.2 respectively, $\mu$ values of $0.025-0.1$ and $L / d$ in the range $15-120$.

Again, it should be emphasized that equation (13) really describes the decrease in the radial effective stress at a given location as more of the pile is driven past. If preferred, an identical equation can be written in terms of the pressure coefficient $K$

$$
\begin{aligned}
K(z) & =\tau_{\mathrm{s}} / \sigma_{\mathrm{v}}{ }^{\prime} \\
& =K_{\min }+\left(K_{\max }-K_{\min }\right) \exp [-\mu(L-z) / d]
\end{aligned}
$$


where $K_{\max }=S_{\mathrm{t}} N_{\mathrm{q}}$, and $K_{\min }$ can be linked to the active earth pressure coefficient $K_{\mathrm{a}}$.

In equations (13) and (14), a number of factors are likely to contribute to the parameter $\mu$, which controls the rate at which the maximum shaft friction is degraded. Principal among these are

(a) compressibility and/or crushability of the surrounding soil

(b) roughness of the pile surface

(c) incremental driving energy needed to advance the pile

(d) effective displacement ratio at the pile tip.

Further research is needed to quantify the effect of these factors. In particular, $(d)$ can be expected to be of major significance, as the extent of the enhanced stress field due to tip penetration will be a function of the effective displacement ratio of the pile, allowing for the degree of plugging of pipe piles.

\section{Compressive and tensile shaft capacities}

There has been considerable discussion of the relative shaft capacity of a pile for compressive and tensile loading. The detailed experimental data of Lehane et al. (1993) show that there are significant changes in radial effective stress during loading, due partly to rotation of principal stress directions and partly to normal strains occurring in the pile and adjacent soil. The effect of principal stress rotation can be quantified only through detailed numerical analysis using sophisticated soil models or through physical experiments. However, the effect of normal strains at the pile-soil interface can be explored more simply.

De Nicola \& Randolph (1993) have described an analysis of the effect of Poisson's ratio expansion and contraction of the pile, and have presented numerical results for a parametric study for a pile wished into place in an elastic-perfectly plastic (Mohr-Coulomb) soil. Most of their numerical analyses were for situations where the effective stress in the soil, and the shear modulus of the soil, varied linearly with depth, and where a non-dilatant interface was introduced between the pile and the soil.

For an initial distribution of horizontal effective stress in the soil $\sigma_{\mathrm{h}}{ }^{\prime}=K_{0} \gamma^{\prime} z$, the ideal shaft friction (for a non-dilatant pile-soil interface) can be written as $\tau_{\mathrm{s}}=K_{0} \gamma^{\prime} z \tan \delta$. Fig. 11 shows typical distributions of radial stress at the pile mid-depth, and shear stress down the pile (normalized to give an average ideal value of unity) at the point of shaft failure for compressive and tensile loading. It is seen that, during compressive loading of the pile, stains in the pile and adjacent soil cause the local radial effective

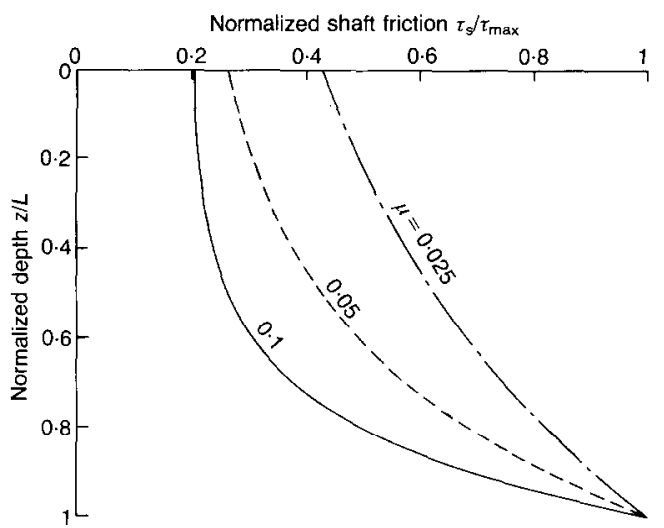

(a)

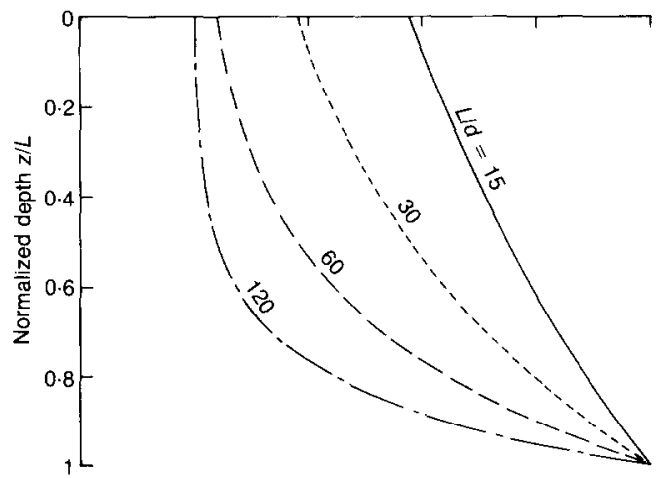

(b)

Fig. 10. Profiles of normalized shaft friction: (a) constant $L / d=50$, varying $\mu$; (b) constant $\mu=0.05$, varying L/d

stresses to rise over most of the pile shaft, the exception being a region within about one diameter of the pile base, where the radial stress reduces. The reverse happens under tensile loading. The difference between the shaft friction for the two modes of loading remains approximately constant over $90 \%$ of the pile. Only near the tip are the relative magnitudes reversed.

The results presented by De Nicola \& Randolph (1993) show that there is a sound theoretical basis for differences between compressive and tensile shaft capacity, the magnitude of the difference being a function of the two quantities

(a) the slenderness ratio $L / d$ for the pile, which causes a fixed ratio of tensile to compressive shaft capacity even for essentially rigid piles or where the value of Poisson's ratio for the pile is zero

(b) the dimensionless group $\eta=v_{\mathrm{p}} \tan \delta$ $(L / d) /\left(E_{\mathrm{p}} / G\right)$, where $E_{\mathrm{p}}$ is the equivalent Young's modulus assuming a solid pile, and $G$ is the average shear modulus of the soil over 


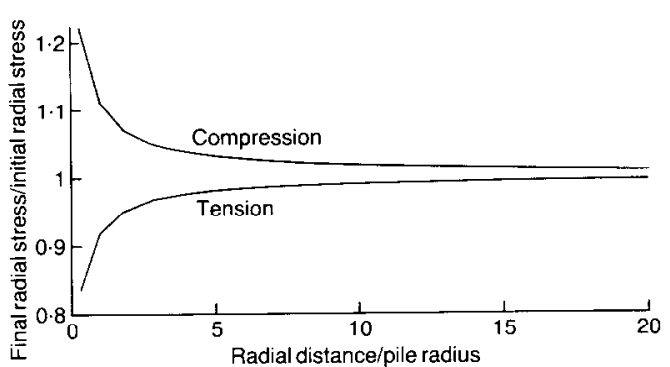

(a)

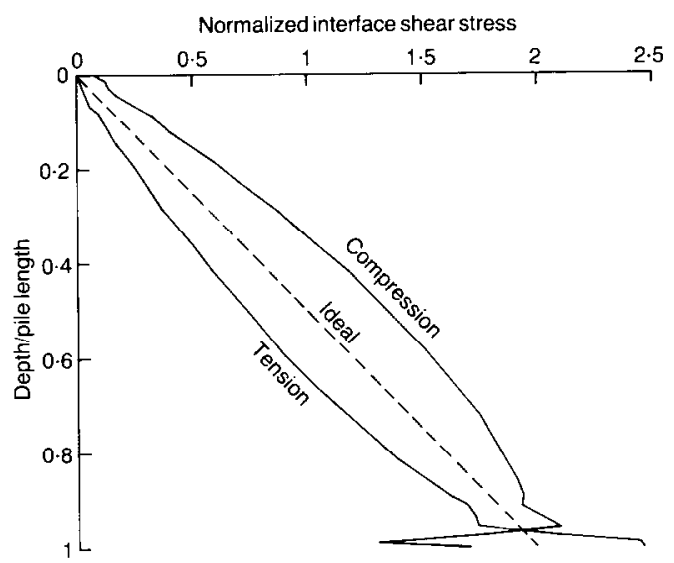

(b)

Fig. 11. Typical stress distributions for compressive and tensile loading: (a) variation of radial stress at pile middepth; (b) variation of shaft friction down pile shaft

the depth of penetration of the pile; the parameter $\eta$ represents a non-dimensional pile compressibility.

The ratio of tensile to compressive shaft capacity in homogeneous sand deposits can be expressed as

$$
\frac{Q_{\mathrm{t}}}{Q_{\mathrm{c}}} \approx\left[1-0 \cdot 2 \log _{10}\left(\frac{100}{L / d}\right)\right]\left(1-8 \eta+25 \eta^{2}\right)
$$

where the term in square brackets should be taken as unity for piles where $L / d$ exceeds 100 . Fig. 12 shows a comparison of the proposed relationship with numerical results.

\section{Summary and sample calculation}

The main principles of the proposed method for estimating the capacity of driven piles in sand can be summarized as follows.

(a) A profile of end-bearing capacity is estimated, either directly from cone penetration data or through solutions for cavity expansion based on appropriate average values of friction and dilation angles, making due allowance for the effect of the ambient stress level on friction angle and shear modulus.

(b) A corresponding profile of peak (or potential) shaft friction is derived from the end-bearing profile, using equation (10).

(c) The actual profile of shaft friction is evaluated, allowing for degradation of shaft friction from the potential value, following equation (13) or equation (14).

(d) The resulting pile shaft capacity is modified according to whether the loading is compressive or tensile, following De Nicola \& Randolph (1993) (Fig. 12).

The design method is illustrated for a hypothetical soil profile consisting of $20 \mathrm{~m}$ of medium to dense sand $\left(\phi_{\mathrm{cv}}=33^{\circ}, I_{\mathrm{d}}=0.8\right)$ overlying less dense silty sand $\left(\phi_{\mathrm{cv}}=29^{\circ}, I_{\mathrm{d}}=0.5\right)$. A pile of diameter $1.5 \mathrm{~m}$ is considered, and profiles of endbearing and shaft friction have been evaluated for pile embedments of $10 \mathrm{~m}, 20 \mathrm{~m}, 30 \mathrm{~m}$ and $50 \mathrm{~m}$,

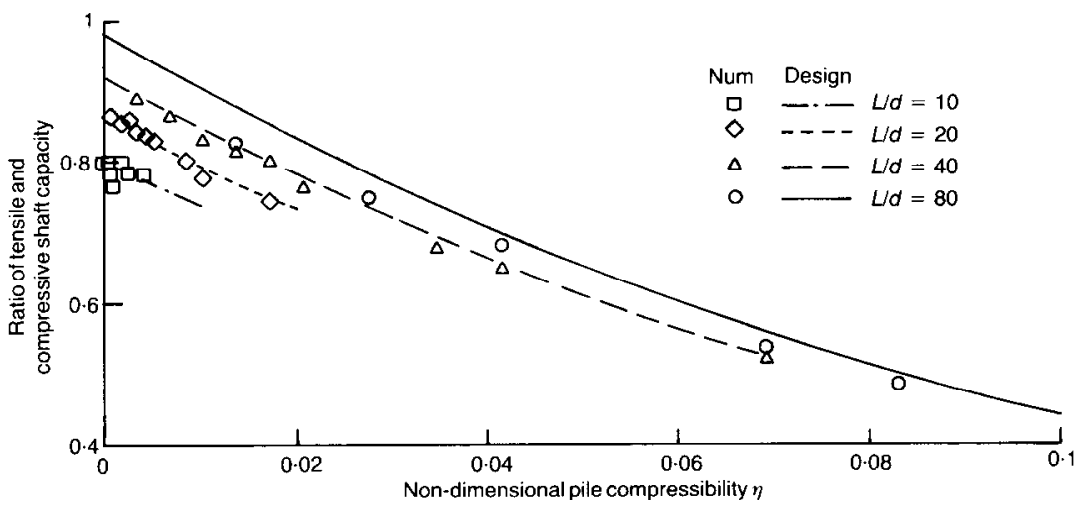

Fig. 12. Ratio of tensile and compressive shaft capacities (De Nicola \& Randolph, 1993) 
assuming a fully-plugged (or closed-ended) pile. The effective unit weight of the soil has been taken as $10 \mathrm{kN} / \mathrm{m}^{3}$, with $K_{0}=0 \cdot 5$. Assumed values of the remaining parameters are

(a) in equation (9): $S=400$ (upper layer) or 200 (lower layer), $c_{1}=0.7, n=0.5$

(b) in equation (12): $a=2, b=7$

(c) in equation (13): $\beta_{\min }=0.2, \mu=0.05$.

Figure 13(a) shows profiles of end-bearing capacity and shaft friction (including $\tau_{\max }$ ). The end-bearing capacity has been assumed to follow a linear transition from three pile diameters above the interface between the two sand types, reaching the reduced value of the lower layer at the interfacc. The effects of degradation of shaft friction with increasing pile embedment is evident. Fig. 13(b) shows the resulting variations of shaft, base and total pile capacity for different pile embedments. As would be expected in relatively uniform sand, the base capacity dominates the pile capacity, particularly at shallow depths. The gradient of shaft capacity with depth from $30 \mathrm{~m}$ to $50 \mathrm{~m}$ corresponds to a limiting shaft friction of just over $100 \mathrm{kPa}$. However, the anticipated distribution of shaft friction down the pile is very different from what would be derived using current design approaches such as the API guidelines.

\section{COMPARISON WITH DATABASE OF PILE LOAD TESTS}

Few research projects have had a sufficient budget to perform large-scale field load tests to explore the axial capacity of piles driven into

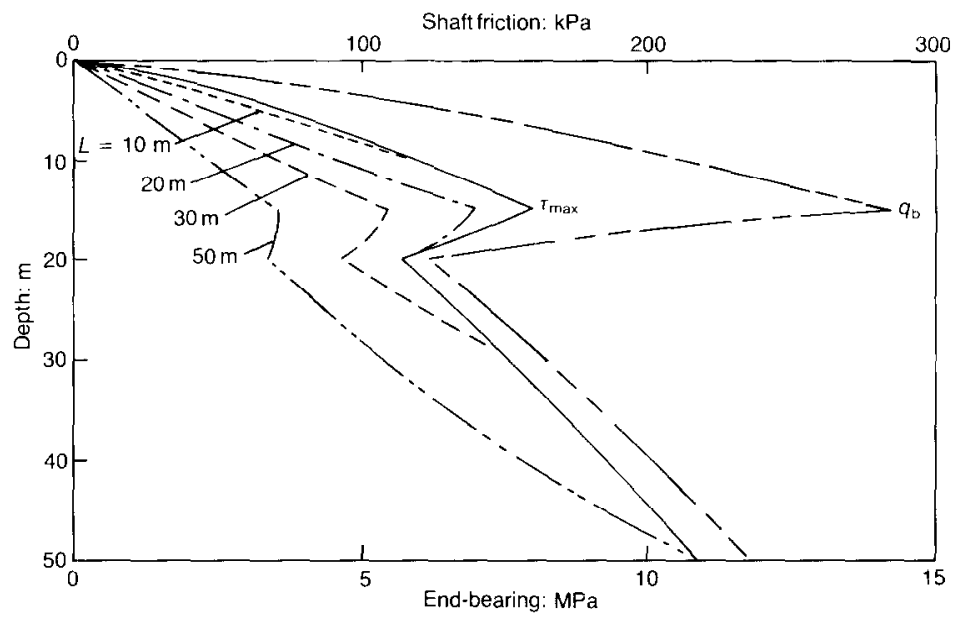

(a)

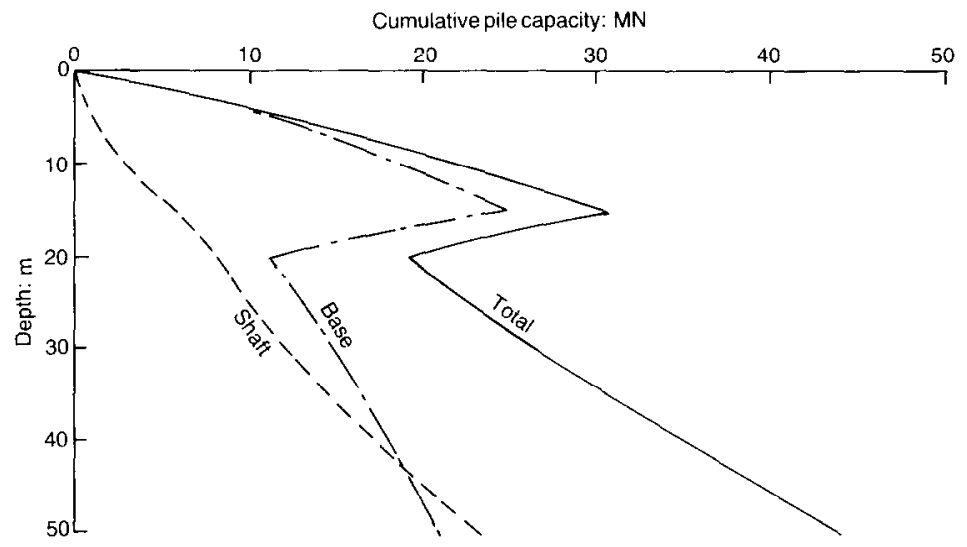

(b)

Fig. 13. Profiles of: (a) shaft friction and end-bearing; (b) shaft, base and total pile capacity 
sand. The database considered here has been drawn exclusively from published data in the geotechnical literature, although other pile tests exist, performed by consortia of oil companies or major geotechnical consultants, which have remained proprietary. Most of the data consist of load tests performed to confirm the capacity of foundation piles during land-based construction projects, and the accompanying soil data are generally very limited. In addition, many of the piles have not been loaded to their ultimate capacity, which introduces significant uncertainties into the comparison with predicted pile capacities.

The database that has been utilized has been restricted to 21 load tests at ten test sites, of which the maximum test load is $500 \mathrm{t}$ (see Table 3). There is uncertainty and inconsistency in the definition of the ultimate capacity of piles, particularly during compressive loading; the values given in Table 3 have been taken from the papers referenced.

\section{End-bearing capacity}

Cavity expansion theory as described has been used to calculate the end-bearing capacity for the database piles, with open-ended piles assumed fully plugged. Table 4 lists parameters that have been adopted; in broad terms the policy was to adopt values of $\phi_{\mathrm{cv}}=33^{\circ}$ in a clean sand and $\phi_{\mathrm{cv}}=27-30^{\circ}$ in silty sand (depending on the proportion of silt). In silty material, the shear modulus coefficient $S$ (see equation (9)) was reduced from 400 in accordance with Table 2.

Figure 14 compares calculated and measured end-bearing capacity. There is significant scatter and a trend showing the ratio of measured endbearing to calculated end-bearing to reduce with increasing penetration of the pile. (A virtually identical plot is obtained if the pile penetration is normalized by pile diameter.) Also plotted in Fig. 14 are ratios of measured pile end-bearing to cone resistance. These follow a very similar trend to the ratio of measured to calculated end-bearing, and cast some doubt on the reliability of the reported end-bearing capacities. Possible explanations for the underestimation of the measured end-bearing capacity are underestimated residual compressive loads at the pile tip, and insufficient displacement of the pile during the load test. These factors would tend to become more significant as the pile penetration increased.

\section{Shaft friction}

Most load tests in the database show shaft friction increasing to a peak and then decreasing near the tip of the pile. A few (e.g. those on pile H12 from Vésic, 1970) show a completely different, and rather unlikely, trend, with peak shaft friction occurring near ground level. Fig. 15 shows examples of measured shaft friction profiles for some of the database piles. Calculated profiles of shaft friction are shown for comparison.

The following secondary effects tend to confuse trends in the data

(a) layering within the soil strata at the test site

(b) internal skin friction in open-ended piles leading to very high shaft friction near the pile tip (e.g. Mey, Oteo, Sanchez Del Rio \& Seriano, 1985)

(c) residual stresses due to installation not accounted for when estimating measured values of shaft friction; as discussed by Kraft (1990), these tend to lead to underestimation of the end-bearing capacity and overestimation of shaft friction near the pile tip.

Six of the load tests in the database allowed comparison of the shaft friction profile at ultimate

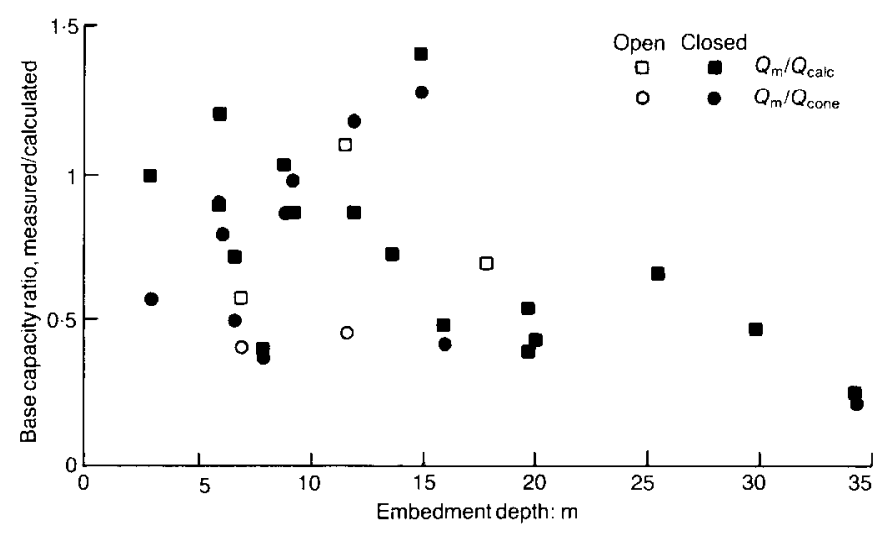

Fig. 14. Comparison of base capacity with calculated values and cone resistance 


\begin{tabular}{|c|c|c|c|c|c|c|c|}
\hline \multicolumn{2}{|c|}{ 总 } & 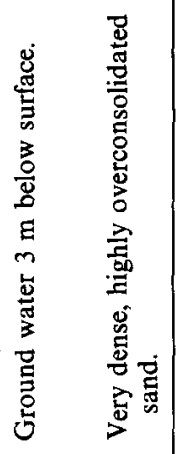 & 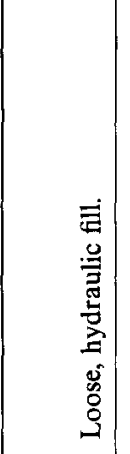 & & 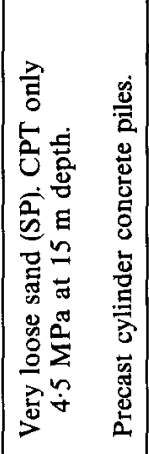 & 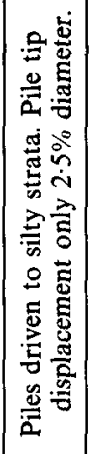 & \\
\hline & إ. & $\stackrel{+}{\doteq} \stackrel{\infty}{\oplus}$ & $\overline{0}$ & $\stackrel{2}{\circ}$ & $\dot{\partial} \quad 9$ & $\tilde{\dot{\nu}} \overline{\dot{m}}$ & $\stackrel{\leftrightarrow}{\dot{q}}$ \\
\hline 要 & 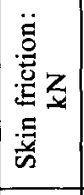 & 있 & 焉 & \%ั & 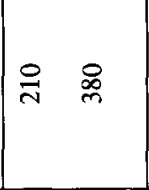 & \%일 & 8 \\
\hline & 童 & 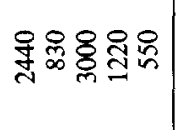 & 总 & 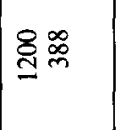 & 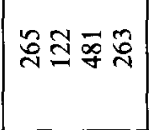 & 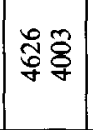 & 58 \\
\hline & $\stackrel{2}{2}$ & 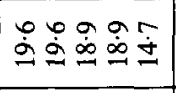 & 品 & | & 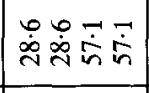 & g 7 & $\begin{array}{l}\infty \\
\infty \\
0 \\
n\end{array}$ \\
\hline & 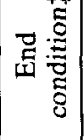 & 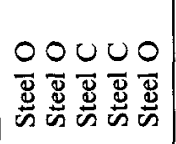 & 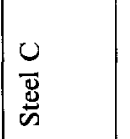 & 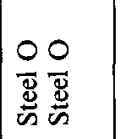 & 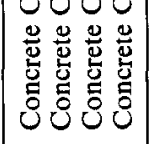 & 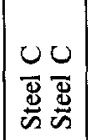 & 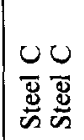 \\
\hline & 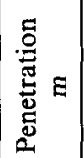 & $\ln \hat{\dot{\theta}} \tilde{\dot{n}}$ & 2 & $\stackrel{0}{=}$ & $\infty \infty \simeq$ & 完 & 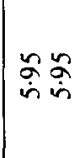 \\
\hline & 离 & 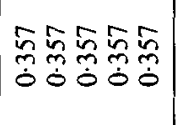 & 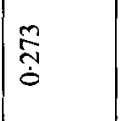 & 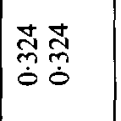 & 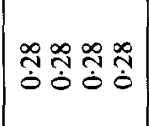 & 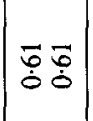 & $\overrightarrow{0} \overrightarrow{0}$ \\
\hline & 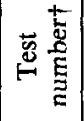 & 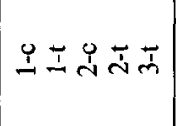 & 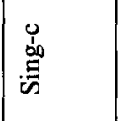 & 岁苟 & 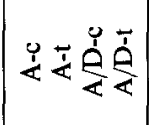 & 是早 & 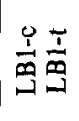 \\
\hline 产 & & 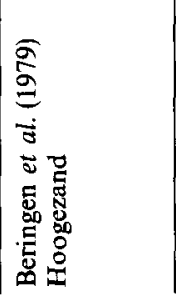 & 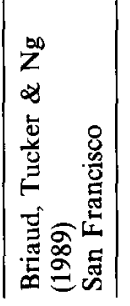 & 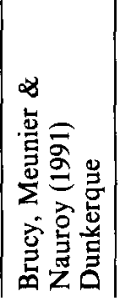 & 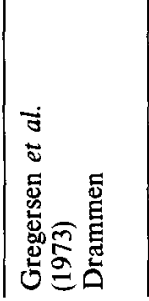 & 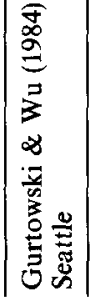 & 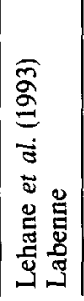 \\
\hline
\end{tabular}




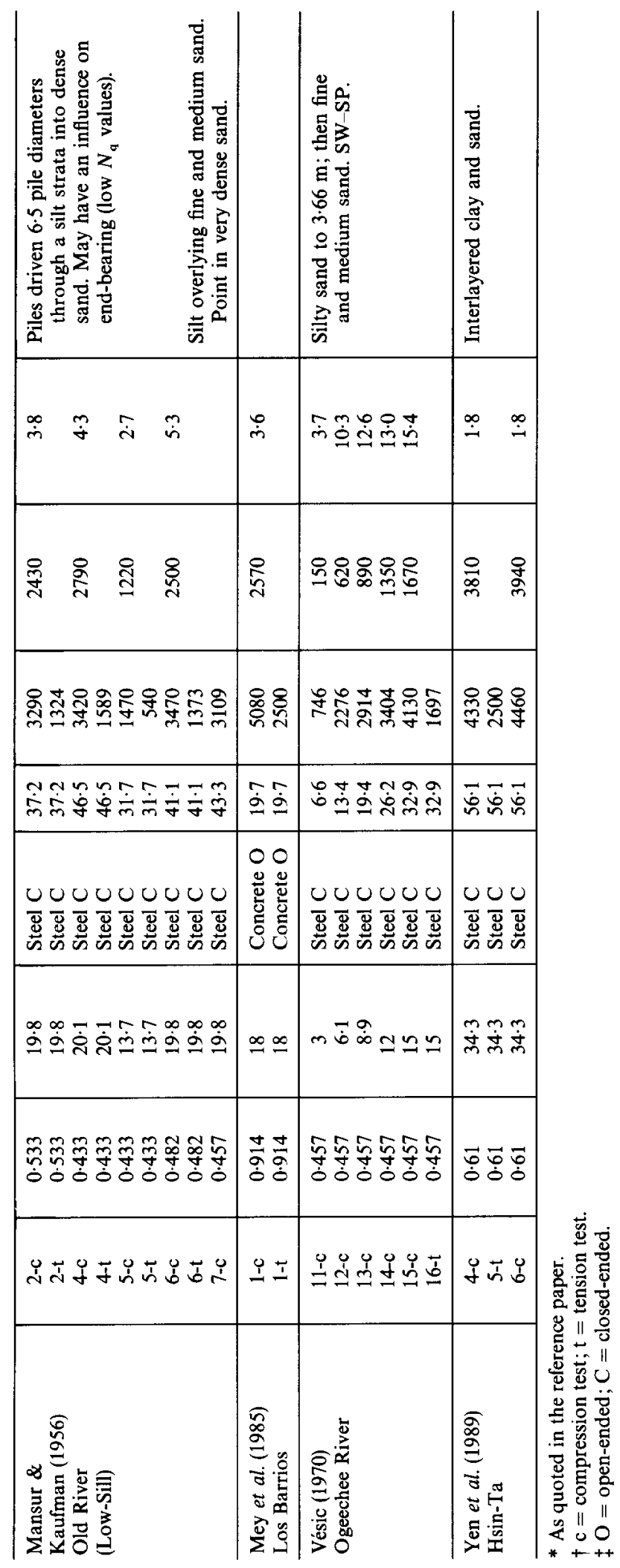


Table 4 (below and facing page). Calculation of capacity for database piles

\begin{tabular}{|c|c|c|c|c|c|c|c|c|}
\hline \multirow[t]{2}{*}{ Source paper } & \multicolumn{2}{|c|}{ Test pile } & \multicolumn{2}{|c|}{ Cone data } & \multicolumn{4}{|c|}{ Interpreted soil data } \\
\hline & Number & $L / d$ & $\begin{array}{l}Q_{\mathrm{c}}: \\
\mathrm{MPa}\end{array}$ & $\begin{array}{l}F_{\mathrm{r}}: \\
\%\end{array}$ & $I_{\mathrm{d}}$ & $\begin{array}{l}\sigma_{\mathrm{v}}{ }^{\prime}: \\
\mathbf{k P a}\end{array}$ & $\begin{array}{l}\phi_{\mathrm{cv}}: \\
\text { deg }\end{array}$ & $K_{0}$ \\
\hline $\begin{array}{l}\text { Beringen et al. (1979) } \\
\text { Hoogezand }\end{array}$ & $\begin{array}{l}1-c \\
2-c\end{array}$ & $\begin{array}{l}19 \cdot 6 \\
18 \cdot 9\end{array}$ & $\begin{array}{l}28 \cdot 0 \\
28 \cdot 0\end{array}$ & $\begin{array}{l}1 \cdot 0 \\
1 \cdot 0\end{array}$ & $\begin{array}{l}0.90 \\
0.90\end{array}$ & $\begin{array}{l}100 \\
100\end{array}$ & $\begin{array}{l}33 \\
33\end{array}$ & $\begin{array}{l}1.5 \\
1.5\end{array}$ \\
\hline $\begin{array}{l}\text { Briaud et al. (1989) } \\
\text { San Francisco }\end{array}$ & Sing-c & $33 \cdot 5$ & $6 \cdot 2$ & 1.7 & 0.50 & 100 & 33 & 0.4 \\
\hline $\begin{array}{l}\text { Brucy et al. (1991) } \\
\text { Dunkerque }\end{array}$ & CS-c & $35-6$ & $20 \cdot 0$ & - & 0.60 & 141 & 30 & 0.5 \\
\hline $\begin{array}{l}\text { Gregersen et al. (1973) } \\
\text { Drammen }\end{array}$ & $\begin{array}{c}\text { A-c } \\
\text { A/D-c }\end{array}$ & $\begin{array}{l}28 \cdot 6 \\
57 \cdot 1\end{array}$ & $\begin{array}{l}2 \cdot 5 \\
4 \cdot 5\end{array}$ & - & $\begin{array}{l}0.25 \\
0.25\end{array}$ & $\begin{array}{r}90 \\
170\end{array}$ & $\begin{array}{l}30 \\
30\end{array}$ & $\begin{array}{l}0 \cdot 4 \\
0 \cdot 4\end{array}$ \\
\hline $\begin{array}{l}\text { Gurtowski \& Wu (1984) } \\
\text { Seattle }\end{array}$ & $\begin{array}{l}\text { A-c } \\
\text { B-c }\end{array}$ & $\begin{array}{l}49 \cdot 0 \\
42 \cdot 0\end{array}$ & - & - & $\begin{array}{l}0 \cdot 50 \\
0.50\end{array}$ & $\begin{array}{l}330 \\
275\end{array}$ & $\begin{array}{l}27 \\
27\end{array}$ & $\begin{array}{l}0 \cdot 5 \\
0 \cdot 5\end{array}$ \\
\hline $\begin{array}{l}\text { Lehane et al. (1993) } \\
\text { Labenne }\end{array}$ & LB1-c & $58 \cdot 3$ & $5 \cdot 0$ & - & $0 \cdot 40$ & 79 & 33 & 0.5 \\
\hline $\begin{array}{l}\text { Mansur \& } \\
\text { Kaufman (1956) } \\
\text { Old River } \\
\text { (Low-Sill) }\end{array}$ & $\begin{array}{l}2-c \\
4-c \\
5-c \\
6-c\end{array}$ & $\begin{array}{l}37 \cdot 2 \\
46 \cdot 5 \\
31 \cdot 7 \\
41 \cdot 1 \\
\end{array}$ & $\begin{array}{l}- \\
- \\
-\end{array}$ & $\begin{array}{l}- \\
- \\
-\end{array}$ & $\begin{array}{l}0 \cdot 50 \\
0 \cdot 50 \\
0 \cdot 40 \\
0 \cdot 50\end{array}$ & $\begin{array}{l}200 \\
200 \\
140 \\
200\end{array}$ & $\begin{array}{l}30 \\
30 \\
27 \\
30\end{array}$ & $\begin{array}{l}0 \cdot 7 \\
0 \cdot 7 \\
0.7 \\
0 \cdot 7\end{array}$ \\
\hline $\begin{array}{l}\text { Mey et al. (1985) } \\
\text { Los Barrios }\end{array}$ & $1-\mathrm{c}$ & $19 \cdot 7$ & - & - & 0.50 & 180 & 27 & $0 \cdot 6$ \\
\hline $\begin{array}{l}\text { Vésic (1970) } \\
\text { Ogeechee River }\end{array}$ & $\begin{array}{l}11-\mathrm{c} \\
12-\mathrm{c} \\
13-\mathrm{c} \\
14-\mathrm{c} \\
15-\mathrm{c}\end{array}$ & $\begin{array}{r}6 \cdot 6 \\
13 \cdot 4 \\
19 \cdot 4 \\
26 \cdot 2 \\
32 \cdot 9\end{array}$ & $\begin{array}{r}6 \cdot 5 \\
13 \cdot 0 \\
14 \cdot 5 \\
11 \cdot 0 \\
12 \cdot 0\end{array}$ & $\begin{array}{l}2 \cdot 9 \\
2 \cdot 1 \\
1 \cdot 9 \\
2 \cdot 5 \\
2 \cdot 3\end{array}$ & $\begin{array}{l}0.50 \\
0 \cdot 80 \\
0.90 \\
0.90 \\
0 \cdot 80\end{array}$ & $\begin{array}{r}45 \\
76 \\
103 \\
135 \\
165\end{array}$ & $\begin{array}{l}30 \\
33 \\
33 \\
33 \\
31\end{array}$ & $\begin{array}{l}0 \cdot 5 \\
0 \cdot 5 \\
0 \cdot 5 \\
0 \cdot 5 \\
0 \cdot 5\end{array}$ \\
\hline $\begin{array}{l}\text { Yen et al. (1989) } \\
\text { Hsin-Ta }\end{array}$ & $\begin{array}{l}4-c \\
6-c\end{array}$ & $\begin{array}{l}56 \cdot 1 \\
56 \cdot 1\end{array}$ & $\begin{array}{l}8 \cdot 0 \\
8 \cdot 0\end{array}$ & - & $\begin{array}{l}0.50 \\
0.50\end{array}$ & $\begin{array}{l}321 \\
321\end{array}$ & $\begin{array}{l}30 \\
30\end{array}$ & $\begin{array}{l}0 \cdot 6 \\
0 \cdot 6\end{array}$ \\
\hline
\end{tabular}

* Values of $S$ refer to equation (9).

tensile and compressive capacity, and these have been discussed by De Nicola \& Randolph (1993). Two phenomena were apparent

(a) the mobilized shaft friction during tensile loading is less than that during compressive loading; typically, the tensile capacity is approximatcly $80 \%$ of the compressive capacity, as proposed by Toolan et al. (1990)

(b) an effect occurs in the friction profile near the pile tip that is opposite for the two loading types, generating increased friction for tensile loading and decreased friction for compressive loading.

These two effects are consistent with the results of numerical analysis reported by De Nicola \& Randolph (1993). Any error in assessing the residual load distribution will affect the comparison of shaft friction in tension and compression, but the average shaft friction in tension and compression should be independent of any errors due to residual loads.

Figure 16 shows the ratio of measured to calculated shaft capacity of the piles in the database. In general, the calculated shaft capacities are too low. However, the underestimation of shaft capacity complements the overestimation of endbearing capacity (particularly as the pile embedment increases), and these two effects can be attributed partly to errors in the experimental data arising from residual forces in the pile at the end of installation.

\section{Total pile capacity}

The total measured pile capacity is plotted against the measured pile capacity in Fig. 17. For all the pile tests, the average ratio of calculated to 
Table 4-continued

\begin{tabular}{|c|c|c|c|c|c|c|}
\hline \multicolumn{3}{|c|}{ Calculated capacity } & \multicolumn{3}{|c|}{ Prediction ratios } & \multirow[t]{2}{*}{ Notes* } \\
\hline $\begin{array}{l}\text { Ultimate: } \\
\mathrm{kN}\end{array}$ & $\begin{array}{l}\text { Skin friction: } \\
\mathrm{kN}\end{array}$ & $\begin{array}{c}\text { End-bearing: } \\
\text { MPa }\end{array}$ & $\begin{array}{c}\text { Skin friction } \\
Q_{\mathrm{m}} / Q_{\mathrm{c}}\end{array}$ & $\begin{array}{c}\text { End-bearing } \\
Q_{m} / Q_{c}\end{array}$ & $\begin{array}{l}\text { Total } \\
Q_{\mathrm{m}} / Q_{\mathrm{c}}\end{array}$ & \\
\hline $\begin{array}{l}2776 \\
2667\end{array}$ & $\begin{array}{l}780 \\
721\end{array}$ & $\begin{array}{l}19 \cdot 9 \\
19 \cdot 4\end{array}$ & $\begin{array}{l}1 \cdot 68 \\
2 \cdot 12\end{array}$ & $\begin{array}{l}0.57 \\
0.71 \\
\end{array}$ & $\begin{array}{l}0 \cdot 88 \\
1 \cdot 12 \\
\end{array}$ & $\begin{array}{l}\text { Open-ended pile } \\
\text { Closed-ended pile }\end{array}$ \\
\hline 681 & 268 & $7 \cdot 0$ & 0.55 & 0.87 & $0 \cdot 74$ & \\
\hline 1269 & 591 & $8 \cdot 2$ & $0 \cdot 77$ & $1 \cdot 10$ & 0.95 & Open-ended pile \\
\hline $\begin{array}{l}288 \\
607\end{array}$ & $\begin{array}{l}139 \\
366\end{array}$ & $\begin{array}{l}2 \cdot 4 \\
3 \cdot 9\end{array}$ & $\begin{array}{l}1 \cdot 51 \\
1 \cdot 04\end{array}$ & $\begin{array}{l}0.39 \\
0.47\end{array}$ & $\begin{array}{l}0.92 \\
0.79\end{array}$ & $\begin{array}{l}S=200 \text { for loose } \\
\text { condition of sand }\end{array}$ \\
\hline $\begin{array}{l}5253 \\
4793\end{array}$ & $\begin{array}{l}3709 \\
3404\end{array}$ & $\begin{array}{l}5 \cdot 3 \\
4 \cdot 8\end{array}$ & $\begin{array}{l}1 \cdot 08 \\
0 \cdot 91\end{array}$ & $\begin{array}{l}0 \cdot 47 \\
0 \cdot 66\end{array}$ & $\begin{array}{l}0.88 \\
0.84\end{array}$ & $\begin{array}{l}\text { Pile toe in silt. } S=200 \\
\text { Tip displacement }<2 \cdot 5 \% \\
\text { diameter }\end{array}$ \\
\hline 87 & 47 & $5 \cdot 1$ & $1 \cdot 28$ & $0 \cdot 89$ & $1 \cdot 12$ & \\
\hline $\begin{array}{l}3888 \\
2849 \\
1159 \\
3282\end{array}$ & $\begin{array}{r}1711 \\
1384 \\
612 \\
1501\end{array}$ & $\begin{array}{r}9 \cdot 8 \\
10 \cdot 0 \\
3 \cdot 7 \\
9 \cdot 8\end{array}$ & $\begin{array}{l}1.42 \\
2 \cdot 02 \\
1.99 \\
1 \cdot 67\end{array}$ & $\begin{array}{l}0.39 \\
0.43 \\
0.72 \\
0.54\end{array}$ & $\begin{array}{l}0 \cdot 85 \\
1 \cdot 20 \\
1 \cdot 27 \\
1 \cdot 06\end{array}$ & $\begin{array}{l}\text { For silt layer } 5-14 \mathrm{~m} \\
\phi_{\mathrm{cv}}=27^{\circ} \\
I_{\mathrm{d}}=0 \cdot 40, K_{0}=0.7 \\
S=200\end{array}$ \\
\hline 5952 & 2569 & $5 \cdot 2$ & 1.00 & 0.69 & 0.85 & $\begin{array}{l}\text { Some silt content } \\
S=200\end{array}$ \\
\hline $\begin{array}{r}734 \\
1814 \\
2721 \\
3645 \\
3294\end{array}$ & $\begin{array}{r}127 \\
406 \\
718 \\
1195 \\
1503\end{array}$ & $\begin{array}{r}3 \cdot 7 \\
8 \cdot 6 \\
12 \cdot 2 \\
14 \cdot 9 \\
10 \cdot 9\end{array}$ & $\begin{array}{l}1 \cdot 18 \\
1 \cdot 53 \\
1 \cdot 24 \\
1 \cdot 13 \\
1 \cdot 11\end{array}$ & $\begin{array}{l}1.00 \\
1.20 \\
1.03 \\
0.87 \\
1.41\end{array}$ & $\begin{array}{l}1 \cdot 02 \\
1.25 \\
1.07 \\
0.93 \\
1.25\end{array}$ & \\
\hline $\begin{array}{l}5271 \\
5271\end{array}$ & $\begin{array}{l}3158 \\
3158\end{array}$ & $\begin{array}{l}7 \cdot 2 \\
7 \cdot 2\end{array}$ & $\begin{array}{l}1 \cdot 21 \\
1 \cdot 25\end{array}$ & $\begin{array}{l}0 \cdot 25 \\
0 \cdot 25\end{array}$ & $\begin{array}{l}0.82 \\
0.85\end{array}$ & $\begin{array}{l}\text { Very high silt content } \\
S=75\end{array}$ \\
\hline \multicolumn{3}{|c|}{$\begin{array}{l}\text { Mean } \\
\text { Standard deviation }\end{array}$} & $\begin{array}{l}1.32 \\
0.41\end{array}$ & $\begin{array}{l}0.73 \\
0.30\end{array}$ & $\begin{array}{l}0.99 \\
0.16\end{array}$ & \\
\hline
\end{tabular}

measured capacity is 0.99 , with a standard deviation of 0.16. Overall, therefore, the proposed design method can be viewed as acceptable. As given in Table 4, the mean ratio of ealculated to measured capacities is 1.32 for the shaft friction (standard deviation of 0.41 ) and 0.73 for endbearing (standard deviation of $0 \cdot 30$ ). The poor agreement of measured end-bearing with cone resistance (Fig. 14) casts some doubt on the reported separation of measured pile capacities into shaft and base components. However, further research is needed to explore this apparent discrepancy in the two components of pile capacity, and to quantify the design parameters within the proposed method with greater confidence.

Overall, the pile load database is very limited in terms of soil properties and of measured load distributions which do not appear to be consistent with the reported soil description. However, taking simplified profiles of soil parameters, and with minimal tuning of parameters and limited allowance for different soil layers, the overall pile capacities predicted using the proposed design method appear reasonable.

\section{CONCLUSIONS}

The design framework outlined in this Paper contains many areas that require further research in order to calibrate the proposed expressions. However, the aim has been to present an approach that is linked closely with the physical processes involved and is sufficiently flexible to allow modification as new data become available.

In the proposed framework, the shaft friction along the pile is tied directly into the profile of end-bearing capacity, and it is therefore important that this profile be established with reason- 
able accuracy. This can be achieved through cone data, or can be estimated in terms of the limit pressure for spherical cavity expansion. The latter approach requires knowledge of

(a) the in situ relative density

(b) the ultimate friction angle $\phi_{\mathrm{cv}}$

(c) the shear modulus $G$.

Quantities (a) and (b) should be measured (or estimated) routinely in any site investigation, although it is interesting that information on relative density is lacking in many of the published reports that form the current database of pile load tests. Interpretation of in situ tests in terms of the state variable (Been, Crooks, Becker \& Jefferies, 1986, 1987) would provide equivalent information. It is also essential in any future research on pile capacity in sand that appropriate field and laboratory tests be undertaken to establish the variation of shear modulus with mean effec-

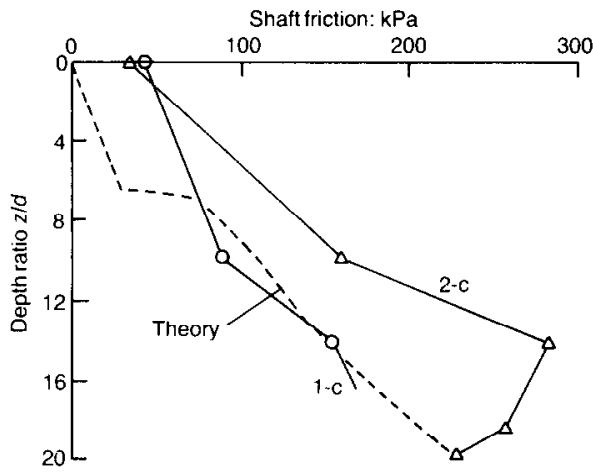

(a)

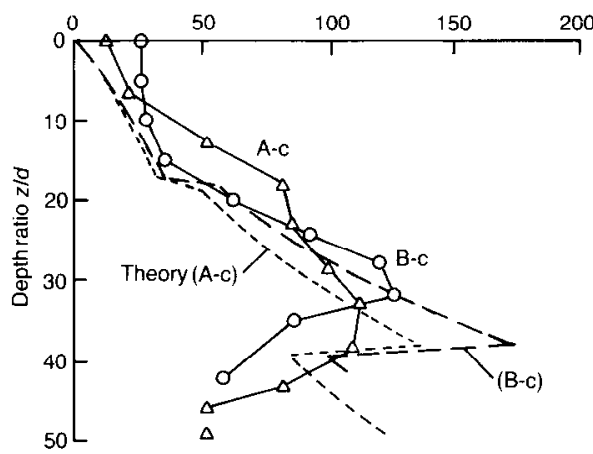

(c)

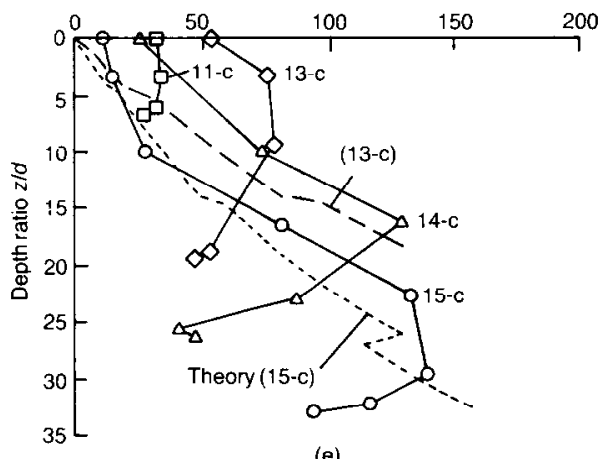

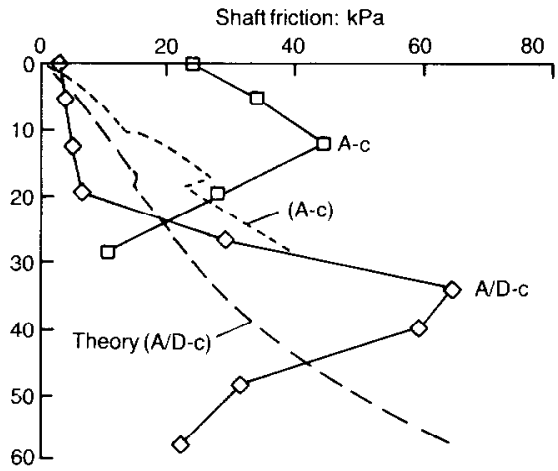

(b)

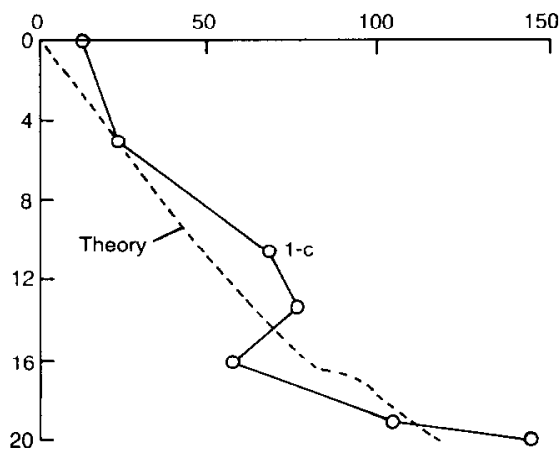

(d)

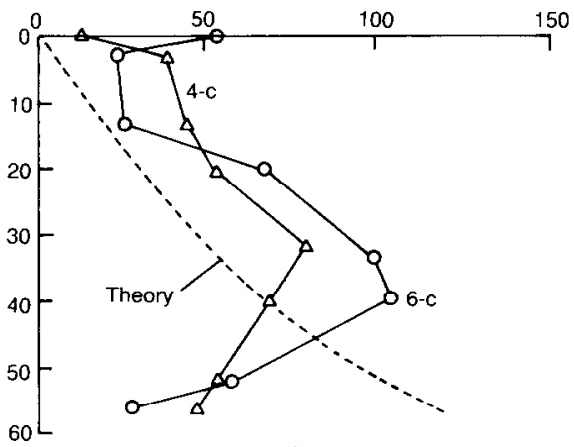

(f)

Fig. 15. Skin friction profiles from selected database piles: (a) Beringen et al. (1979); (b) Gregersen, Aas \& Dibagio (1973); (c) Gurtowski \& Wu (1984); (d) Mey et al. (1985); (e) Vésic (1970); (f) Yen, Lin \& Chin (1989) 


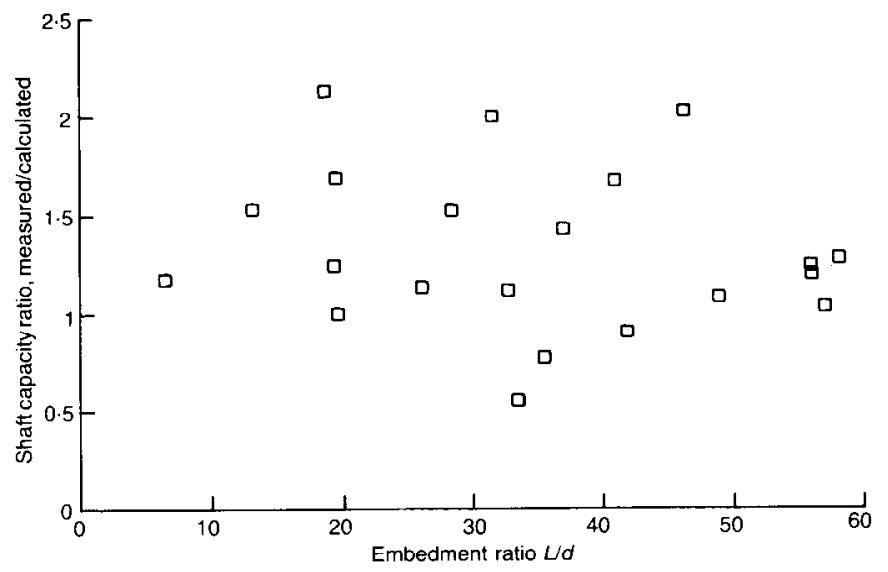

Fig. 16. Comparison of shaft friction capacity

tive stress (and depth). Profiling tools such as the seismic cone, or laboratory tests with internal strain measurement, can provide accurate assessment of the initial, low-strain, shear modulus, which may then be adjusted for application to the strain levels associated with cavity expansion.

Accurate determination of the measured endbearing capacity of field piles is limited by a number of factors, including

(a) uncertainty over residual forces and strains locked into the pile during installation

(b) insufficient displacement of the pile during the loading test, resulting in underestimation of the end-bearing capacity (particularly for relatively long piles)

(c) difficulties with open-ended piles of separating internal and external shaft friction: strain gauges placed near the pile tip will register only the force on the pile annulus, which may be only a small fraction of the total endbearing capacity of the (plugged) pile.

Factor (b) can be addressed readily (at least in research-oriented pile load tests) by ensuring that the pile tip is displaced by at least $20 \%$ of the pile diameter (possibly more if the pile has been driven open-ended with no evidence of partial plugging). However, factors $(a)$ and $(c)$ present a greater problem.

Residual forces remain in driven piles at the end of installation, generally in the form of compressive base stresses balanced by shaft friction that acts downwards on the pile, particularly in the lower half of the pile. The residual force distribution can be estimated from the strain gauge data. However, unless the pile is subjected to preinstallation dynamic forces (such as by driving against a concrete pad), the zeros of most strain gauges will change during installation, as residual

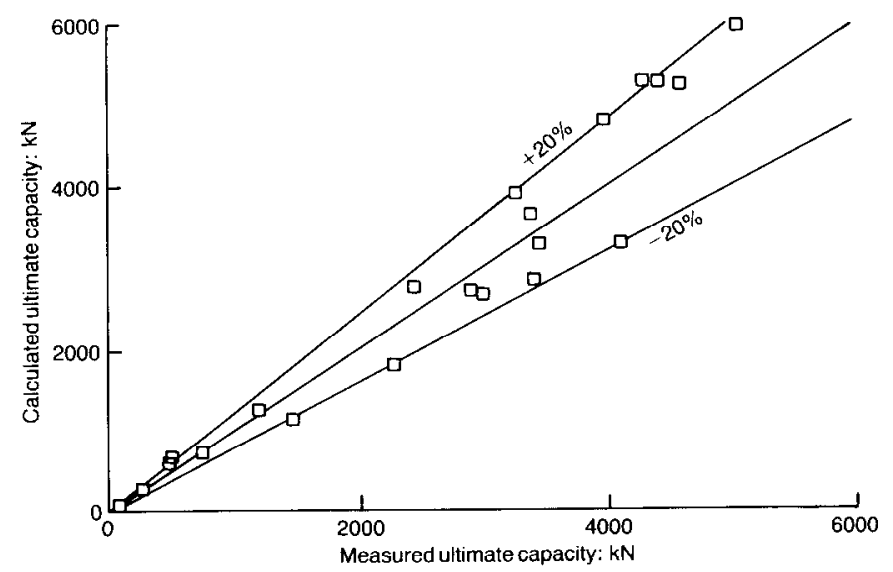

Fig. 17. Comparison of ultimate capacity 
strains due to fabrication are shaken out of the pile. Changes in the local temperature and heatsink environment around each gauge will also affect the zero.

Probably the best approach for estimating the true (post-installation) zeros of strain gauges, and thus evaluating the residual force profile, is to conduct both tension and compression tests on the pile. Tension tests taken to large displacement should result in very low end-bearing stresses acting on the pile (the base stress should approach the hydrostatic pore pressure, as with a fully unloaded pressuremeter test in sand).

The key quantities in the proposed method for estimating shaft friction for piles in sand are

(a) the (peak) ratio of radial effective stress at shaft failure to end-bearing capacity near the pile tip

(b) the relevant interface friction angle $\delta$ for repeated or cyclic slip between pile and soil

(c) the rate of degradation of shaft friction due to further pile penetration

(d) the minimum earth pressure coefficient $K_{\min }$ (and hence $\beta_{\text {min }}$ ) reached for long pile penetration past any given location.

The tests at Ogeechee River (Vésic, 1970) still represent one of the most valuable suites of pile load tests, since profiles of shaft friction were measured at a number of different pile penetrations. In clay soils, pore pressure dissipation during pile installation, and repeated loading of the pile to failure, may have a considerable influence on the final shaft friction profile. However, in sands these considerations apply to a much lesser extent, and field tests should be designed to allow multiple static load testing in compression and tension at different pile penetrations.

Most open-ended piles drive in a partially plugged condition except in very compressible soil, or at shallow depths. This will lead to high end-bearing stresses being developed over the full area of the pile tip, although the region of stress increase will be more confined than for a closedended pile. The conditions for transition from unplugged to partially plugged, or even fully plugged, penetration during driving are poorly understood at present. Equally, the effect of the degree of plugging on the pile shaft capacity is an area of considerable speculation. These areas should be addressed in future research in order to resolve uncertainty over differences in the performance of open-ended and closed-ended piles.

\section{ACKNOWLEDGEMENTS}

The work leading to this Paper was carried out under a contract with Amoco Production Company. The Authors gratefully acknowledge the financial support for the study, and also permission to publish the results. The Authors would also like to acknowledge the constructive comments made by the reviewers of the Paper prior to publication.

\section{NOTATION}

$a, b$ parameters in relationship for $S_{1}$

$c_{1}$ parameter in exponential variation of shear modulus with relative density

$d$ diameter of pile

$e$ void ratio of soil

$E_{\mathrm{p}}$ Young's modulus of pile (assumed solid)

$G$ shear modulus of soil

$G_{0}$ initial tangent shear modulus of soil

$I_{d}$ relative density

$I_{\mathrm{r}}$ rigidity index

$k_{\mathrm{c}}$ ratio of limiting end-bearing pressure to cone resistance

$K$ ratio of radial effective stress at pile surface to in situ vertical effective stress

$K_{\mathrm{a}}$ active earth pressure coefficient

$K_{0}$ at rest earth pressure coefficient

$L$ embedded length of pile

$n$ exponent in shear modulus variation with mean effective stress

$N$ SPT blow-count

$N_{\mathrm{q}}$ bearing capacity factor

$p^{\prime}$ mean effective stress

$p_{\mathrm{a}}$ atmospheric pressure $(100 \mathrm{kPa})$

$p_{\text {lim }}$ limit pressure for spherical cavity expansion

$p_{0}^{\prime}$ in situ mean effective stress

$q_{\mathrm{b}}$ limiting end-bearing pressure

$q_{\mathrm{c}}$ cone resistance

$Q_{c}$ ultimate shaft capacity for compressive loading

$Q_{\text {l }}$ ultimate shaft capacity for tensile loading

$S$ modulus number

$S_{t}$ ratio of radial effective stress to end-bearing pressure in vicinity of pile tip

$z$ depth co-ordinate

$\alpha$ ratio of cone resistance to shaft, and friction angle in cavity expansion calculation of endbearing

$\beta$ ratio of shaft friction to in situ vertical effective stress

$\gamma^{\prime}$ effective unit weight of soil

$\delta$ friction angle for pile-soil interface

$\eta$ non-dimensional pile compressibility

$\mu$ parameter in exponential degradation of shaft friction along pile shaft

$v_{\mathrm{p}}$ Poisson's ratio of pile

$\sigma_{\mathbf{h}}^{\prime}{ }^{\prime}$ in situ horizontal effective stress

$\sigma_{\mathrm{r}}^{\prime}$ radial effective stress at pile shaft

$\sigma_{v}^{\prime}$ in situ vertical effective stress

$\tau_{s}$ limiting shaft friction

$\phi^{\prime} \quad$ effective friction angle of soil

$\phi_{\mathrm{cv}}$ critical state friction angle

$\phi_{\max }$ peak friction angle

$\psi$ dilation angle of soil

\section{REFERENCES}

API (1984). RP2A: recommended practice for planning, designing and constructing fixed offshore platforms, 
15th edn. Washington: American Petroleum Institute.

API (1984). RP2A: recommended practice for planning, designing and constructing fixed offshore platforms, 15th edn. Washington: American Petroleum Institute.

API (1991). RP2A: recommended practice for planning, designing and constructing fixed offshore platforms, 19th edn. Washington: American Petroleum Institute.

Been, K., Crooks, J. H. A., Becker, D. E. \& Jefferies, M. G. (1986). The cone penetration test in sands: I, state parameter interpretation. Géotechnique 36, No. 2, 239-249.

Been, K., Crooks, J. H. A., Becker, D. E. \& Jefferies, M. G. (1987). The cone penetration test in sands: II, general inference of state. Géotechnique 37, No. 3, 285-299.

Beringen, F. L., Windle, D. \& Van Hooydonk, W. R. (1979). Results of loading tests on driven piles in sand. Recent developments in the design and construction of piles, pp. 213-225. London: Institution of Civil Engineers.

Bolton, M. D. (1986). The strength and dilatancy of sands. Géotechnique 36, No. 1, 65-78.

Bolton, M. D. (1987). Discussion on The strength and dilatancy of sands. Géotechnique 37, No. 2, 219-226.

Briaud, J.-L., Tucker, J. L. \& Ng, E. (1989). Axially loaded 5 pile group and single pile in sand. Proc. 12th Int. Conf. Soil Mech., Rio de Janeiro 2, 11211124.

Brucy, F., Meunier, J. \& Nauroy, J.-F. (1991). Behaviour of pile plug in sandy soils during and after driving. Proc. 23rd Ann. Offshore Technol. Conf., Houston, OTC 6514, 145-154.

Bustamante, M. \& Gianeselli, L. (1982). Pile bearing capacity prediction by means of static penetrometer CPT. Proc. 2nd Eur. Symp. Penetration Test., Amsterdam, 493-500.

Carter, J. P., Booker, J. R. \& Yeung, S. K. (1986). Cavity expansion in cohesive frictional soils. Géotechnique 36, No. 3, 349-353.

Collins, I. F., Pender, M. J. \& Wang Yan (1992). Cavity expansion in sands under drained loading conditions. Int. J. Numer. Analy. Meth. Geomech. 16, No. 1, 3-23.

De Nicola, A. \& Randolph, M. F. (1993). Tensile and compressive shaft capacity of piles in sand. $J$. Geotech. Engng Div. Am. Soc. Civ. Engrs 119, No. 12, 1952-1973.

De Ruiter, J. \& Beringen, F. L. (1979). Pile foundations for large North Sea structures. Marine Geotechnol. 3, No. 3, 267-314.

Douglas, B. J. \& Olsen, R. S. (1981). Soil classification using electric cone penetrometer. Proc. Conf. on Cone penetration testing and experience, pp. 209-227. New York: American Society of Civil Engineers.

Fleming, W. G. K., Weltman, A. J., Randolph, M. F. \& Elson, W. K. (1992). Piling engineering, Glasgow: Blackie (Halsted Press). 2nd edn.

Gibson, R. E. (1950). Correspondence. J. Inst. Civ. Engrs 34, 382-383.

Gregersen, O. S., Aas, G. \& Dibagio, E. (1973). Load tests on friction piles in loose sand. Proc. 8th Int. Conf. Soil Mech., Moscow 2, 109-117.
Gurtowski, T. M. \& Wu, M. J. (1984). Compression load test on concrete piles in aluminium. Analysis and design of pile foundations, pp. 138-153. New York: American Society of Civil Engineers.

Hanna, T. H. \& Tan, R. H. S. (1973). The behaviour of long piles under compression loads in sand. Can. Geotech. J. 10, No. 3, 311-340.

Heerema, E. P. (1980). Predicting pile driveability: Heather as an illustration of the friction fatigue theory. Ground Engng 13, Apr., 15-37.

Helfrich, S. C., Wiltsie, E. A., Cox, W. R. \& Al Shafie, K. A. (1985). Pile load tests in dense sand: planning, instrumentation and results. Proc. 17th Offshore Technol. Conf., Houston, OTC 4847, 55-64.

Hossain, M. K. \& Briaud, J.-L. (1991). Critical assessment of existing data for pipe piles in sand subjected to monotonic axial loading. Report. Department of Civil Engineering, Texas A \& M University.

Houlsby, G. T. \& Hitchman, R. (1988). Calibration chamber tests of a cone penetrometer in sand. Géolechnique 38, No. 1, 39-44.

Jardine, R. J., Everton, S. J. \& Lehane, B. M. (1992). Friction coefficients for piles in cohesionless materials. Offshore site investigations and foundation behaviour, pp. 661-680. Dordrecht: Kluwer.

Kishida, H. \& Uesugi, M. (1987). Tests of the interface between sand and steel in the simple shear apparatus. Géotechnique 37, No. 1, 45-52.

Kraft, L. M. (1990). Computing axial pile capacity in sands for offshore conditions. Marine Geotechnol. 9, 61-92.

Kulhawy, F. H. (1984). Limiting tip and side resistance: fact or fallacy? Analysis and design of pile foundations, pp. 80-98. New York: American Society of Civil Engineers.

Lehane, B. M., Jardine, R. J., Bond, A. J. \& Frank, R. (1993). Mechanisms of shaft friction in sand from instrumented pile tests. J. Geotech. Engng Div. Am. Soc. Civ. Engrs 119, No. 1, 19-35.

Lo Presti, D. (1987). Mechanical behaviour of Ticino sand from resonant column tests. Ph.D. thesis, Politecnico di Torino.

Mansur, C. I. \& Kaufman, R. I. (1956). Pile tests, lowsill structure, Old River, Louisiana. Trans. Am. Soc. Civ. Engrs 123, 715-743.

Mey, R., Oteo, C. S., Sanchez Del Rio, J. \& Seriano, A. (1985). Field testing on large driven piles. Proc. 11th Int. Conf. Soil Mech., San Francisco 3, 1559-1564.

Neely, W. J. (1990). Bearing capacity of expanded-base piles in sand. J. Geotech. Engng Div. Am. Soc. Civ. Engrs 116, GT1, 73-87.

Poulos, H. G. \& Davis, E. H. (1980). Pile foundation analysis and design. Chichester: Wiley.

Randolph, M. F. (1985). Capacity of piles driven into dense sand. Report Soils TR 171, Cambridge University Engineering Department.

Richart, F. E., Hall, T. J. \& Woods, R. D. (1970). Vibrations of soils and Foundations, chap. 6. Englewood Cliffs: Prentice-Hall.

Toolan, F. E., Lings, M. L. \& Mirza, U. A. (1990). An appraisal of API RP2A recommendations for determining skin friction of piles in sand. Proc. 22nd offshore Technol. Conf., Houston, OTC 6422, $33-42$.

Vésic, A. S. (1967). A study of bearing capacity of deep 
foundations. Final report, Project B-189, Georgia Institute of Technology, Atlanta.

Vésic, A. S. (1970). Tests on instrumented piles, Ogeechee River site. J. Soil Mech. Fdn Engng Div. Am. Soc. Civ. Engrs 96, SM2, 561-584.

Vésic, A. S. (1975). Bearing capacity of shallow foundation. In Handbook of foundation engineering. New York: Van Nostrand.
Yen, T.-L., Lin, H. \& Chin, C.-T. (1989). Interpretation of instrumented driven steel pipe piles. Foundation engineering: current principles and practices, vol. 2, pp. 1293-1309. New York: American Society of Civil Engineers.

Yu, H. S. \& Houlsby, G. T. (1991). Finite cavity expansion in dilatant soils: loading analysis. Géotechnique 41, No. 2, 173-183. 